\title{
Contribution to the Knowledge of Martinique's Flora (Lesser Antilles)
}

\author{
Kévine Baillard ${ }^{1}$, Philippe Joseph ${ }^{2}$ \\ ${ }^{1}$ PhD Student, Biogeography, Ecology \& Botany, University of the French West Indies, UMR ESPACE DEV/ BIORECA \\ ${ }^{2}$ Doctor and Professor, Biogeography, Ecology \&Botany, University of the French West Indies, UMR ESPACE DEV/BIORECA
}

\begin{abstract}
In tropical island systems, the mesological factors have led to great environmental diversification. These specificities have resulted in a high ecosystemic and specific diversity. In Martinique, as in the other islands of the Lesser Antilles, the rainfall gradients defined the bioclimates. Each bioclimate corresponds to a vegetation floor composed of groups or populations of preponderant species. The phytocenoses observable today in Martinique are called secondary and belong to different dynamic stages. This vegetation is the result of the various human activities which succeeded one another from the colonial period to the present day. The primary vegetation has been strongly modified in favour of intensive monocultures on which the plantation economy was based. Today's secondary vegetation is subject to many pressures linked to demography and multiple human activities. As a result, much of Martinique's plant formations are in little advanced stages. Irrespective of the bioclimate, they are composed of individuals in morphogenetic development accompanied by some mature specimens belonging to a previous dynamic stage. The purpose of this article is to show the organization of plant species communities within the different bioclimatic stages.
\end{abstract}

Keywords: Lesser Antilles, Martinique, Bioclimates, Forest ecosystems, Plant formations

\section{Introduction}

The vegetation distribution and species richness are influenced by several factors such as climate, topography, soil, hydrology and micro-habitat [1-2]. The importance of each factor varies with the spatial scale [1]. The climate is considered to be the predominant factor as the zonal macroscale vegetation results from it (continent or large region) due to geographic gradients of temperature and precipitation $[3,4,2]$.

The vegetation of the Lesser Antilles is a set of vegetation formations determined by eco-climatic conditions and characterised by specific floristic populations [5-6]. In Martinique, as in the other islands of the Lesser Antilles, the altitudinal gradients of the physical factors delimit the bioclimates corresponding to the lower, middle and upper plant floors [7]. The rainfall, which is largely orographic, is the most decisive factor [7]. Today's vegetation is mainly secondary since it is the result of ancient and recent agricultural practices [8]. In fact, in the colonial era, the primitive vegetation (forest) had been largely replaced with monospecific intensive crops (sugar cane, coffee, tobacco, cotton and others) linked to the plantation economy [9-12]. These human activities led to numerous damages such as the extinction of certain plant and animal species [12], soil and sedimentation erosion, quality and quantity changes in water resources [10]. Martinique's vegetation has been exploited for centuries. The naturalization of introduced species and the natural selection of indigenous species have altered the vegetation's composition and structure [13]. The Caribbean (the Larger and Lesser Antilles) has retained only $11.3 \%$ of its primary vegetation [14-16]. In Martinique, the various biotic, abiotic, structuring or anthropogenic parameters have led to plant diversification $[10,2]$ and resulted in floristic mosaics in which the phytocenoses of different dynamic stages coexist $[17,7,18]$.

The objective of this article is to analyse Martinique's vegetation and to show the organisation of plant species communities within the various bioclimatic floors in order to understand the structural and functional processes.

\section{Material}

Intertropical regions are home to a large part of the world's biodiversity. They are characterised by large forest ecosystems of global importance (rainforests, deciduous tropical forests, mangrove forests, coastal forests, etc.[16]. Sixteen global biodiversity hotspots out of twenty-five are located in the tropics [14]. The Caribbean region is one of the regions richest in biodiversity. It was ranked as the third hotspot with just over 12,000 plant species out of which 7,000 are endemic $[14-15,11,19]$. The endemic species in the Caribbean represent $2.3 \%$ of the world's endemic species [14].

Martinique $\left(14^{\circ} 4 \mathrm{~N}^{\mathrm{N}} 61^{\circ} \mathrm{W}\right)$ is an island of volcanic origin (Figure 1) and 


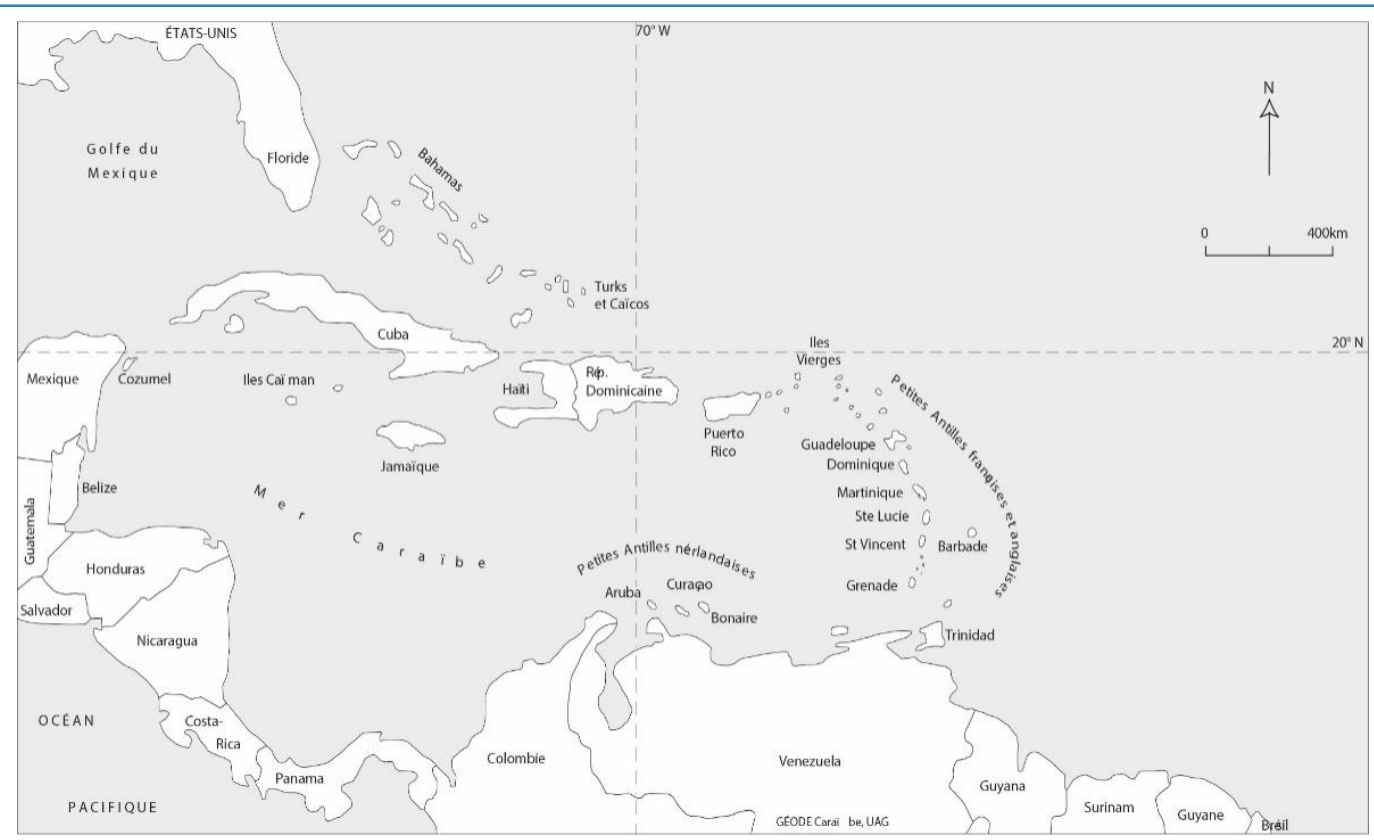

Figure 1: Martinique and the Lesser Antilles in the Caribbean Source: [18]

comprises circa 3200 plant species divided in 1536 native species, 236 allochthonous species (introduced naturalized), 180 cultivated species and crop escapees, 846 cultivated species and 402 dubious species [20]. These 3200 species are also divided into 3181 angiosperms, 14 gymnosperms and 5 prespermaphytes that belong to 200 families [20]. 202 species, subspecies, varieties and hybrids of pteridophytes have also been recorded [21-22]. Some tree species are endemic to the Lesser Antilles, at archipelago or island scale. Sapiumcaribaum, Eugenia hodgei, Pisoniasuborbiculata, Clusia major, Sterculiacaribaea,
Sloaneadentataare species endemic to the Lesser Antilles [23, 20]. In Martinique, for example, Myrciamartinicensisis endemic $[23,20]$.

In Martinique, as in the other islands of the Lesser Antilles, there are three vegetation floors whose limits vary according to the slopes. These lower, middle and upper plant floors are respectively influenced by dry sub-wet, wet and wet subhumid bioclimates (Table 1 and Figure 2) [7, 24, 18]. Each plant floor is characterised by a group of species from which the biotopes condition the individual phytocenoses (Figure 2) $[18]$.

Table 1:Ecosystem potential in Martinique

\begin{tabular}{|c|c|c|c|c|}
\cline { 2 - 5 } \multicolumn{1}{c|}{} & Altitude & $\begin{array}{c}\text { Annual mean } \\
\text { rainfall }\end{array}$ & Bioclimates & Ecosystem potential \\
\hline Lower floor & $0-250 \mathrm{~m}$ & $1500 \mathrm{~mm}$ & Dry Bioclimate & $\begin{array}{c}\text { Seasonal tropical evergreen forest of lower horizon and } \\
\text { xeric facies (dry forest), Mangrove, Ripisylva, } \\
\text { Psammophilous formations, cliff formations, } \\
\text { Herbaceous and/or shruby formations }\end{array}$ \\
\hline Middle floor & $250-500 \mathrm{~m}$ & $1500-2500 \mathrm{~mm}$ & $\begin{array}{c}\text { Moderately wet } \\
\text { Bioclimate }\end{array}$ & $\begin{array}{c}\text { Tropical seasonal evergreen forest (mesophilic forest) } \\
\text { Upper floor }\end{array}$ \\
more than $500 \mathrm{~m}$ & $2500-4000 \mathrm{~mm}$ & Wet Bioclimate & $\begin{array}{c}\text { Tropical sub-montane ombrophilous forest } \\
\text { (hygrophilous forest) }\end{array}$ \\
\cline { 2 - 5 } & more than $4000 \mathrm{~mm}$ & Hyper-wet Bioclimate & $\begin{array}{c}\text { Tropical montane ombrophilous forest (montane } \\
\text { hygrophilous forest) }\end{array}$ \\
\hline
\end{tabular}

According to $[7,24,6,18,25]$

Volume 6 Issue 1, January 2017 www.ijsr.net 


\section{International Journal of Science and Research (IJSR) \\ ISSN (Online): 2319-7064}

Index Copernicus Value (2015): 78.96 | Impact Factor (2015): 6.391

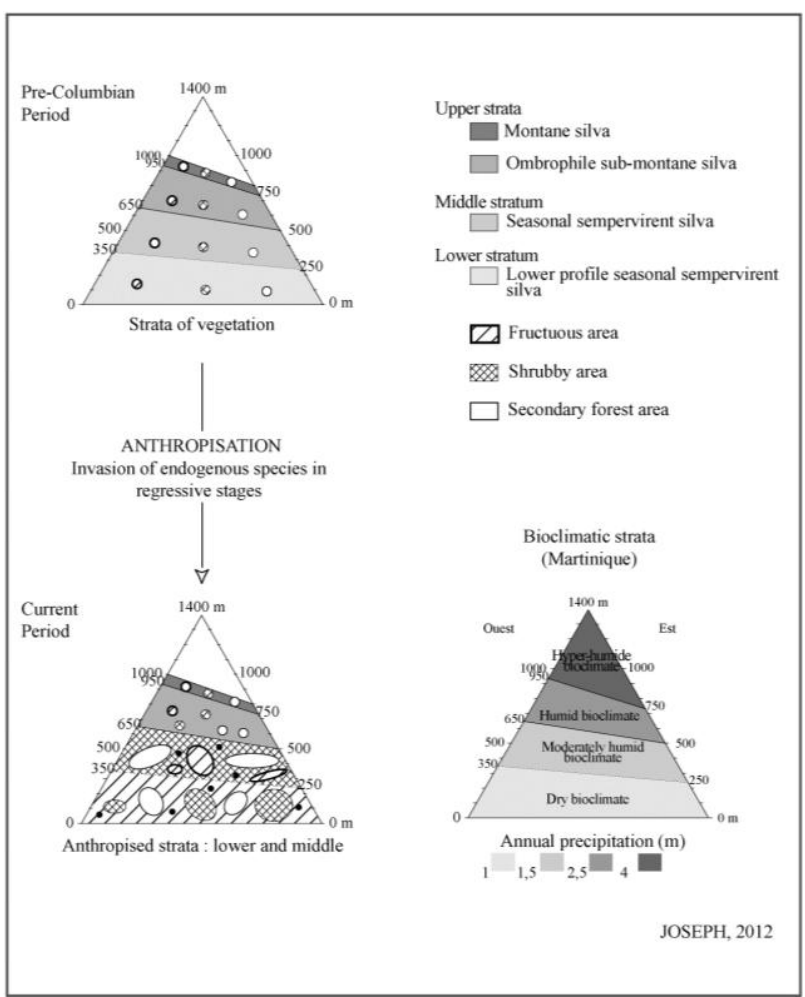

Figure 2: Vegetation evolution in Martinique from preColumbian times and bioclimatic floors Source: [18]

\section{Method}

The analysis of plant formations is based on nine floristic surveys of various sizes (from $450 \mathrm{~m}^{2}$ to $1440 \mathrm{~m}^{2}$; Figures 4 to 12) influenced by three bioclimates. These nine surveys correspond to three station groups, each consisting of three surveys of the same geographical area. Each group of surveys is influenced by a bioclimate or even distinct mesological parameters and is located in the GrosMorne, Marin and Vauclin towns (Figure 3; Table 3). This approach allows us to make intra-station (between transects) and extra-station (between stations) comparisons.

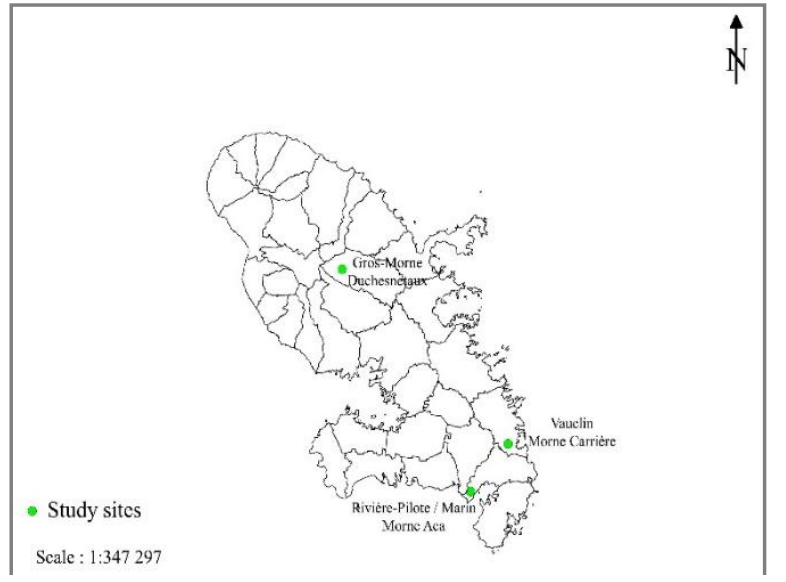

Figure 3: Study Sites

The surveys carried out in the form of transects divided into quadrats allow us to characterize the vegetation formations, to analyse their structure, their dynamics, the ecological processes, the organisation of the species, to define their environmental and bioclimatic affinities and to observe the evolution of the vegetation cover. We used several descriptors in each transect: species (of all physiognomic types), number of individuals of the plant species populations (from seedlings to mature individuals), diametric classes, height classes and first ramification classes.

Using these raw quantitative data, several treatments allowed us to analyse and assess the plant communities:

- Absolute frequency $=$ presence of the species in the different quadrats [7, 6, 18, 24-37];

- Relative frequency = Absolute frequency /per number of quadrats (in \%) [7, 6, 18, 24-37];

- Distribution index (Id) = Relative frequency $\times$ Density (Density $=$ number of individuals/survey area) $[7,6,18$, 24-37];

- Dominance index (ID) $=$ Distribution index $\times$ Land surface or basal area (the Surface area corresponds to the sum of the surfaces of the circles constituted by the sections measured at 1.33 meters from the ground) [7, 6, 18, 24-37];

- Diameter and height distribution.

The frequencies are used to assess the presence of species in the quadrats, stations and between the quadrats and stations. The index of distribution allows us to know the distribution of the species between the transect quadrats and between the stations. The Dominance index allows us to assess the importance of the species in relation to each other within the relevant plant formation. The diameter and height distribution gives us information about the architecture of the formations and the level of demographic development of the species populations.

\section{Results and Discussions}

\subsection{General characteristics of the stations}

The total floristic populations studied comprises 174 species distributed in 118 genera and belonging to 61 families (Tables 2 and 3). 5150 individuals have been recorded for a total surface area of $6630 \mathrm{~m}^{2}$. Two families are the best represented: The Rubiaceae (16 species, 9 genera) and the Myrtaceae (14 species, 6 genera).

Stations 4, 5 and 6 influenced by the wet sub-humid bioclimate exhibit the greatest specific diversity (Tables 2, 3, 4) with the highest number of individuals, species, genera and families (Table 2). Table 2 shows that station 4 has the most consistent basal area; station 5 has the most important demography and station 6 is the first in terms of density, number of species and genera. 


\section{International Journal of Science and Research (IJSR) \\ ISSN (Online): 2319-7064}

Index Copernicus Value (2015): 78.96 | Impact Factor (2015): 6.391

Table 2: General characteristics of the stations

\begin{tabular}{|c|c|c|c|c|c|c|c|}
\cline { 2 - 8 } \multicolumn{1}{c|}{} & Area $\left(\mathrm{m}^{2}\right)$ & $\begin{array}{c}\text { Number of } \\
\text { individuals }\end{array}$ & $\begin{array}{c}\text { Number } \\
\text { of species }\end{array}$ & $\begin{array}{c}\text { Number } \\
\text { of genera }\end{array}$ & $\begin{array}{c}\text { Number of } \\
\text { families }\end{array}$ & $\begin{array}{c}\text { Total density } \\
\left.\text { (individual per } m^{2}\right)\end{array}$ & Basal area \\
\hline Station 1 & 1440 & 182 & 50 & 43 & 35 & 0.123838889 & 5.645621875 \\
\hline Station 2 & 480 & 142 & 44 & 37 & 29 & 0.295833333 & 5.7089125 \\
\hline Station 3 & 450 & 204 & 34 & 28 & 21 & 0.453333333 & 3.02225 \\
\hline Station 4 & 960 & 848 & 54 & 43 & 28 & 0.883333333 & 6.027328125 \\
\hline Station 5 & 700 & 1032 & 37 & 31 & 22 & 1.474285714 & 4.63935 \\
\hline Station 6 & 500 & 786 & 55 & 45 & 33 & 1.572 & 3.002625 \\
\hline Station 7 & 800 & 635 & 47 & 40 & 31 & 0.79375 & 2.59933125 \\
\hline Station 8 & 700 & 697 & 37 & 31 & 26 & 0.995714286 & 2.57381875 \\
\hline Station 9 & 600 & 624 & 35 & 29 & 23 & 1.04 & 2.015978125 \\
\hline
\end{tabular}

Table 3: Physical characteristics of the stations by station group

\begin{tabular}{|l|c|c|c|c|c|c|}
\cline { 2 - 7 } \multicolumn{1}{c|}{} & Town & Bioclimate & $\begin{array}{c}\text { Minimal to Maximal } \\
\text { Average Temperature }\end{array}$ & Pluviometry & Soil type & Altitude \\
\hline Stations 1, 2, 3 & GrosMorne & Wet & $21^{\circ}-29^{\circ}$ & $3500-4500 \mathrm{~mm}$ & $\begin{array}{c}\text { Allophane soils } \\
\text { (andosols) }\end{array}$ & $290-370 \mathrm{~m}$ \\
\hline Stations 4, 5, 6 & Marine & Wet sub-humid & $23^{\circ}-29^{\circ}$ & $1600-1800 \mathrm{~mm}$ & $\begin{array}{c}\text { Vertisols and rust } \\
\text { brown halloytes soils }\end{array}$ & $200-250 \mathrm{~m}$ \\
\hline Stations 7, 8, 9 & Vauclin & Sub-wet dry & $23^{\circ}-28^{\circ}$ & $1500-1600 \mathrm{~mm}$ & $\begin{array}{c}\text { Vertisols and rust } \\
\text { brown halloytes soils }\end{array}$ & $150-200 \mathrm{~m}$ \\
\hline
\end{tabular}

According to [38 - 39]

Table 4: Station group data

\begin{tabular}{|c|c|c|c|c|c|}
\cline { 2 - 6 } \multicolumn{1}{c|}{} & $\begin{array}{c}\text { Total stations area } \\
\left(\mathrm{m}^{2}\right)\end{array}$ & $\begin{array}{c}\text { Total number of } \\
\text { individuals }\end{array}$ & $\begin{array}{c}\text { Total number } \\
\text { of species }\end{array}$ & $\begin{array}{c}\text { Total number } \\
\text { of genera }\end{array}$ & $\begin{array}{c}\text { Total number of } \\
\text { families }\end{array}$ \\
\hline Stations $1,2,3$ & 2370 & 528 & 74 & 52 & 38 \\
\hline Stations $4,5,6$ & 2160 & 2666 & 82 & 62 & 40 \\
\hline Stations $7,8,9$ & 2100 & 1956 & 66 & 57 & 39 \\
\hline
\end{tabular}

\subsection{The area/species ratios}

The floristic survey must be a representative sample of the studied vegetation formation. Its surface must be equal to or even greater than the minimal area in order to identify the majority of the species (at least 80\%) that make up the overall floristic population of a given geographical area [40]. The minimal area corresponds to the minimal space required by a plant community to reach the development to which the normal specific set corresponds [41, 40]. It is defined using the area-species curve.
The studied stations vary in size (from 450 to $1140 \mathrm{~m}^{2}$; Table 2). The surface of a survey is determined according to the mesological, ecological, architectural and structural parameters of the vegetation formation (strata, dynamic stage and bioclimate). Stations 2, 5 and 8 did not reach the minimal area (Figures 5, 8, 11). The curves are in constant evolution from the first to the last quadrat. The survey surface of stations 1, 3, 6, 7 and 9 is greater than the minimal area (Figures 4, 6, 9, 10, 12). Station 4 contains two biocenoses: the minimal area is reached at $560 \mathrm{~m}^{2}$ (quadrat 7) where the curve stabilizes before starting to grow again from $720 \mathrm{~m}^{2}$ (quadrat 9) (Figure 7).

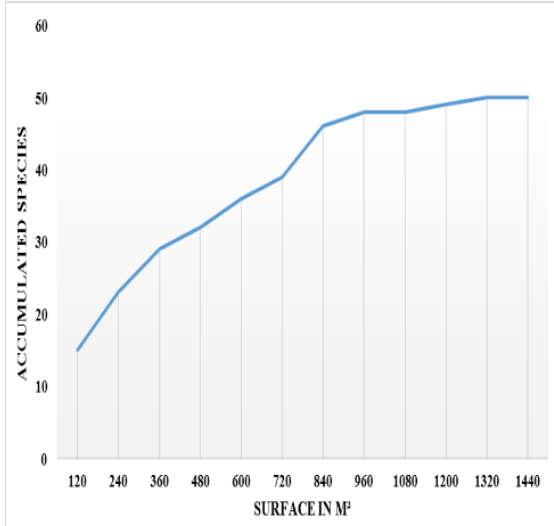

Figure 4: Area-species curve station 1
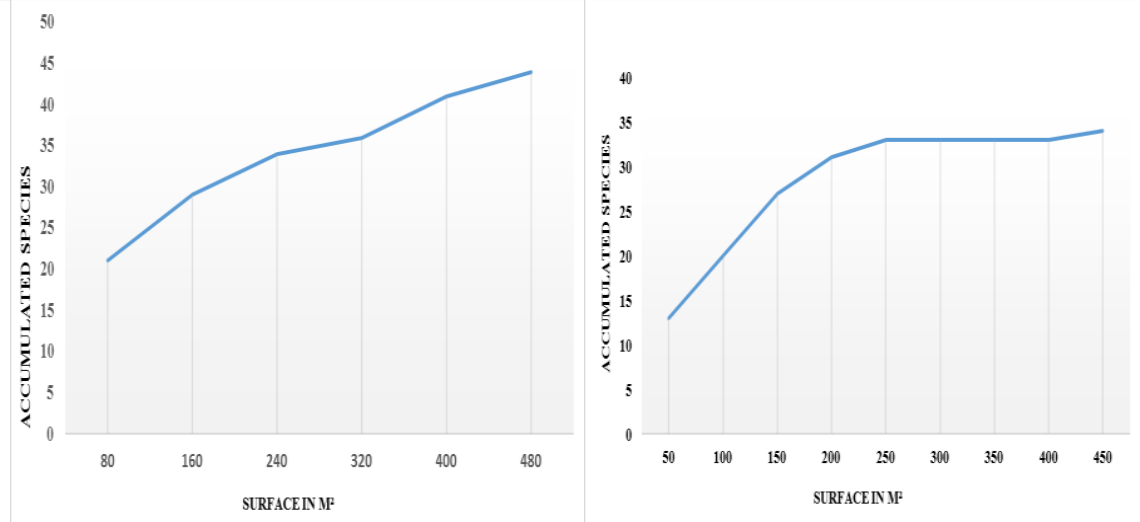

Figure 5: Area-species curve station 2 Figure 6: Area-species curve station 3

\section{Volume 6 Issue 1, January 2017 www.ijsr.net}




\section{International Journal of Science and Research (IJSR) \\ ISSN (Online): 2319-7064}

Index Copernicus Value (2015): 78.96 | Impact Factor (2015): 6.391
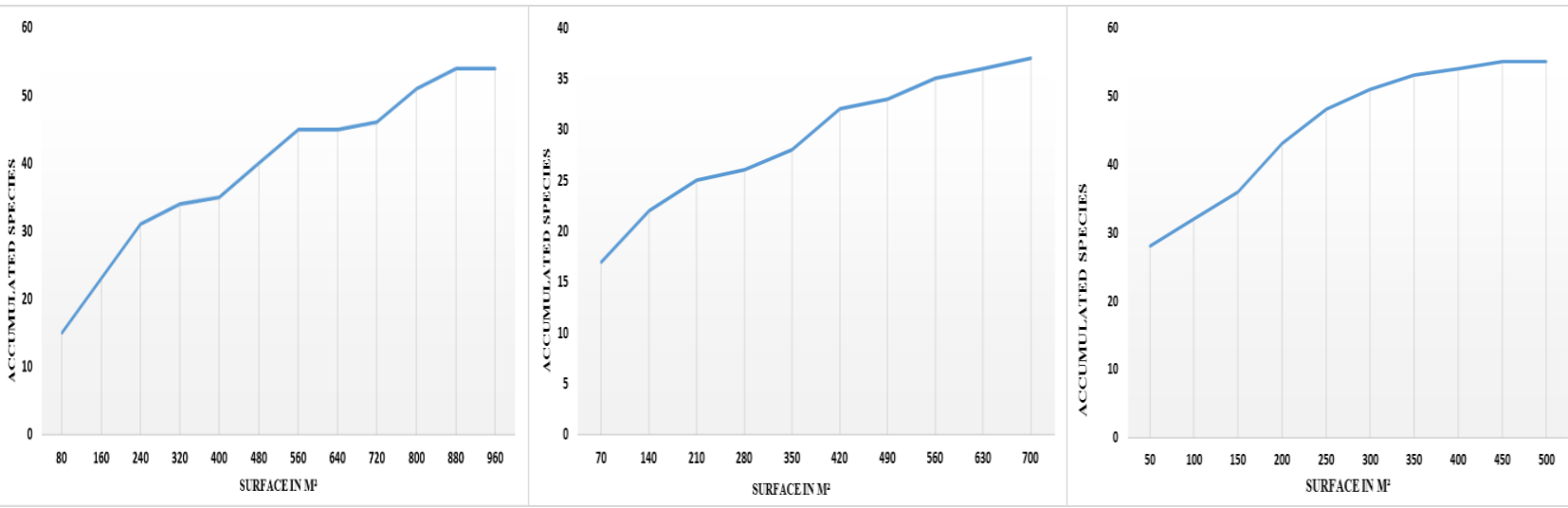

Figure 7: Area-species curve station

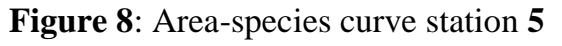

Figure 9: Area-species curve station 6
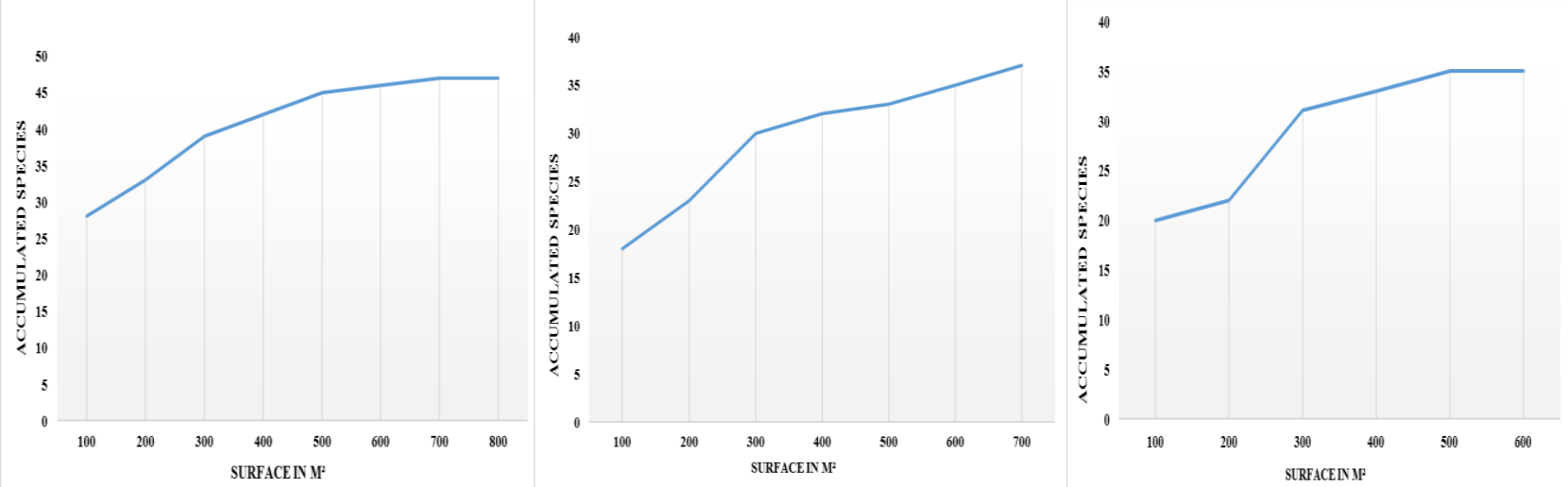

Figure 10: Area-species curve station 7 Figure 11: Area-species curve station 8 Figure 12: Area-species curve station 9

\subsection{The main ecological, architectural and structural parameters of the stations}

Station $1\left(1440 \mathrm{~m}^{2}\right.$, Riverside Terrace, Table 5)

Table 5: Main descriptors of station 1

\begin{tabular}{|c|c|c|c|c|c|c|c|c|}
\hline Species & Family & $\begin{array}{c}\text { Absolute } \\
\text { Frequency }\end{array}$ & $\begin{array}{c}\text { Relative } \\
\text { Frequency }\end{array}$ & $\begin{array}{c}\text { Number of individuals } \\
\text { by species excluding } \\
\text { regeneration }\end{array}$ & Density & $\begin{array}{c}\text { Distribution } \\
\text { Index }\end{array}$ & $\begin{array}{c}\text { Total basal } \\
\text { area by species }\end{array}$ & $\begin{array}{c}\text { Index of } \\
\text { dominance }\end{array}$ \\
\hline Chimarrhiscymosa & Rubiaceae & 8 & $67 \%$ & 23 & 0.01597222 & 0.01064815 & 1.0224625 & 0.010887332 \\
\hline Pouteria multiflora & Sapotaceae & 7 & $58 \%$ & 20 & 0.01388889 & 0.00810185 & 0.829646875 & 0.006721676 \\
\hline Dacryodesexcelsa & Burseraceae & 7 & $58 \%$ & 14 & 0.00972222 & 0.0056713 & 0.74084375 & 0.004201544 \\
\hline
\end{tabular}

Tropical riverside seasonal ombrophilous evergreen forest (hygrophilous), degraded and damaged by cyclones. This high surface station is characterised by low biodemography, high mortality and a grass carpet. Chimarrhiscymosa is the preponderant species with the highest land surface (basal area) and distribution and dominance indices (Table 5). Its population is quasi-balanced with seedlings, regenerations and individuals of various diameters $(2.5$ to $80 \mathrm{~cm}$; Figure 13). The number of individuals by species, the densities and distribution indices of the species are low, but some of them have high land surfaces. No species is present in all quadrats. Most of the individuals in this station are small (2.5 and 5 $\mathrm{cm}$ in diameter) and peak between 1 and $8 \mathrm{~m}$ (Figure 14).
This configuration is due in particular to the natural hazards which caused the environment disturbances. This formerly advanced vegetation unit is in regression and is currently undergoing a regeneration or even transition phase. The mortality rate in this station is $31 \%$. Dead trees or trees dead on the ground are specimens with important biovolumes (30 to $70 \mathrm{~cm}$ in diameter). The dead and living mature individuals belong to a past vegetative dynamics and indicate a modification of the environment. This discontinuous (open) vegetation unit is still dominated by a tree stratum in different stages of development and evolution (2.5 to $80 \mathrm{~cm}$; Figures 13 and 14) associated with regenerations of various sizes and grasses. 


\section{International Journal of Science and Research (IJSR) \\ ISSN (Online): 2319-7064}

Index Copernicus Value (2015): 78.96 | Impact Factor (2015): 6.391

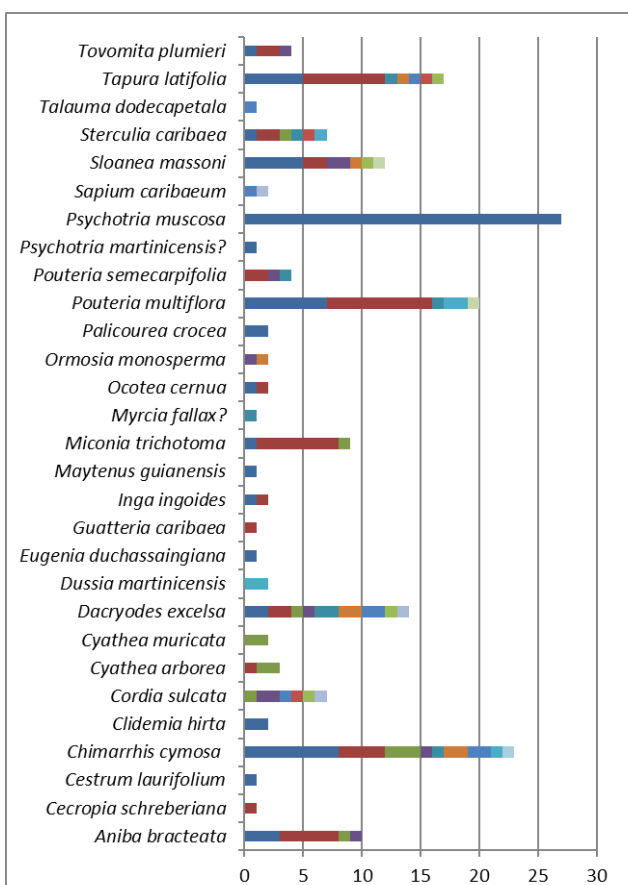

Figure 13: Diametric distribution of trees Station 2 (480 $\mathrm{m}^{2}$, Table 6)

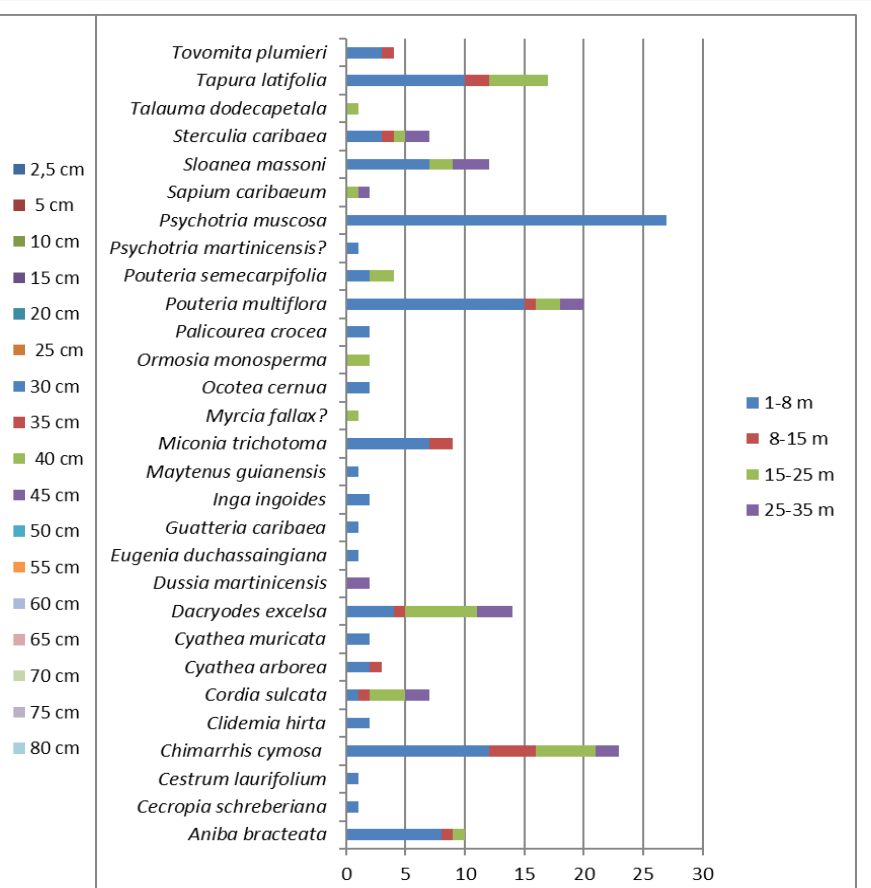

Figure 14: Distribution of tree heights

Table 6: The main descriptors of station 2

\begin{tabular}{|c|c|c|c|c|c|c|c|c|}
\hline Species & Family & $\begin{array}{c}\text { Absolute } \\
\text { Frequency }\end{array}$ & $\begin{array}{c}\text { Relative } \\
\text { Frequency }\end{array}$ & $\begin{array}{c}\text { Number of } \\
\text { individuals by } \\
\text { species excluding } \\
\text { regeneration }\end{array}$ & Density & $\begin{array}{c}\text { Distribution } \\
\text { Index }\end{array}$ & $\begin{array}{c}\text { Total basal area } \\
\text { by species }\end{array}$ \\
$\begin{array}{c}\text { Index of } \\
\text { dominance }\end{array}$ \\
\hline Swieteniaaubrevilleana & Meliaceae & 5 & $83 \%$ & 16 & 0.03333333 & 0.027777778 & 1.3874875 & 0.03854132 \\
\hline Anibabracteata & Lauraceae & 6 & $100 \%$ & 25 & 0.05208333 & 0.052083333 & 0.220290625 & 0.01147347 \\
\hline Chimarrhiscymosa & Rubiaceae & 3 & $50 \%$ & 4 & 0.00833333 & 0.004166667 & 1.22815125 & 0.00533964 \\
\hline Dacryodesexcelsa & Burseraceae & 3 & $50 \%$ & 3 & 0.00625 & 0.003125 & 1.6897125 & 0.00528035 \\
\hline
\end{tabular}

Tropical seasonal ombrophilous evergreen forest (hygrophilous), damaged. Swieteniaaubrevilleanais the dominant species. Anibabracteata is present in all quadrats and has the largest population (Table 6). Three individuals with important biovolumes (class 50, 95 and $100 \mathrm{~cm}$; Figure 15) allow Dacryodesexcelsa to have the highest basal area. Chimarrhiscymosa ranks third in order of ecological importance and biomass with four individuals (Table 6).
Two-thirds of the individuals have a $2.5 \mathrm{~cm}$ diameter and a height between 1 and $8 \mathrm{~m}$ (Figures 15 and 16). This vegetation unit includes small stems associated with a few Swieteniaaubrevilleana,

Dacryodesexcelsa and Chimarrhiscymosawith large diameters and belonging to one or several previous dynamic stages (Figure 15). 


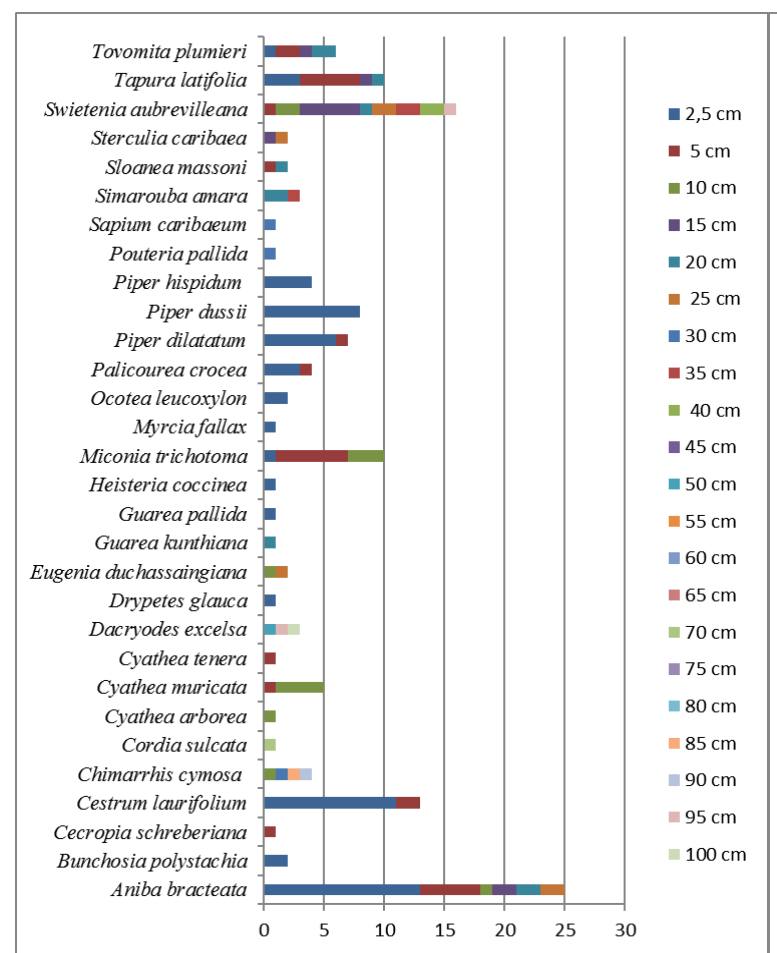

Figure 15: Diametric distribution of trees

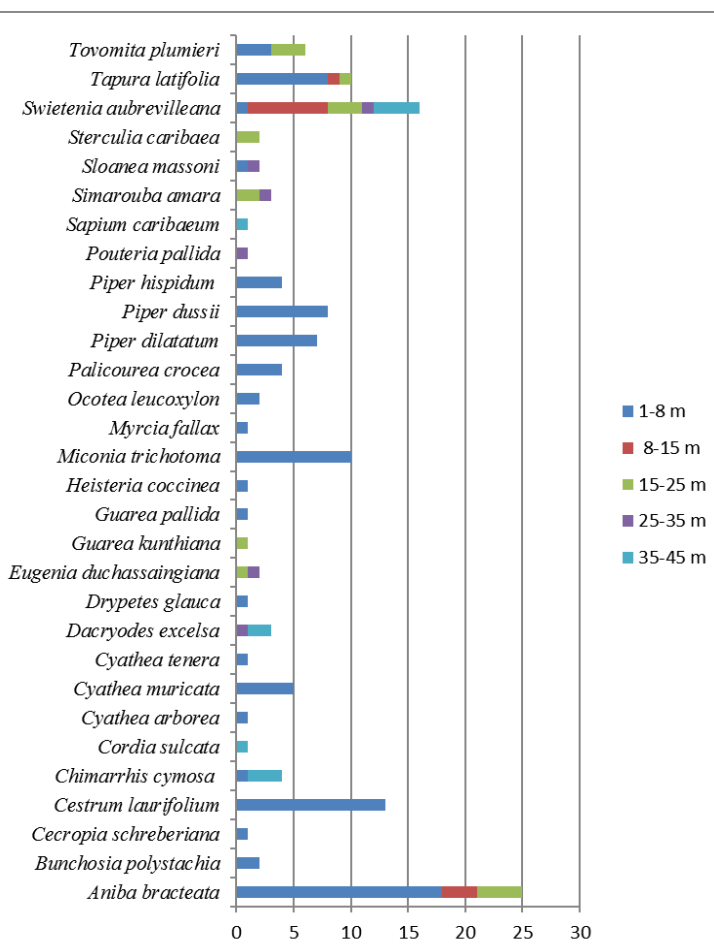

Figure 16: Distribution of tree heights Station 3 (450 $\mathrm{m}^{2}$, Table 7)

Table 7: The main descriptors of station 3

\begin{tabular}{|c|c|c|c|c|c|c|c|c|}
\hline Species & Family & $\begin{array}{c}\text { Absolute } \\
\text { Frequency }\end{array}$ & $\begin{array}{c}\text { Relative } \\
\text { Frequency }\end{array}$ & \begin{tabular}{|c|} 
Number of \\
individuals by \\
species \\
excluding \\
regeneration \\
\end{tabular} & Density & $\begin{array}{c}\text { Distribution } \\
\text { Index }\end{array}$ & $\begin{array}{c}\text { Total basal } \\
\text { area by } \\
\text { species }\end{array}$ & $\begin{array}{c}\text { Index of } \\
\text { dominance }\end{array}$ \\
\hline Swieteniaaubrevilleana & Meliaceae & 7 & $78 \%$ & 13 & 0.02888889 & 0.022469136 & 1.8977375 & 0.042640522 \\
\hline Tapuralatifolia & Dichapetalaceae & 8 & $89 \%$ & 83 & 0.18444444 & 0.163950617 & 0.08144375 & 0.013352753 \\
\hline Swieteniamacrophylla & Meliaceae & 5 & $56 \%$ & 5 & 0.01111111 & 0.00617284 & 0.6417375 & 0.003961343 \\
\hline
\end{tabular}

Tropical seasonal ombrophilous evergreen forest (hygrophilous). Swieteniaaubrevilleana is the dominant species with the highest basal area (Table 7). Tapuralatifolia has the largest population. Nevertheless, this species is in regeneration $(2.5-10 \mathrm{~cm}$ in diameter and $1-8$ in height; Figures 17 and 18). Five individuals of large volumes allow Swieteniamacrophylla to be the third species in order of ecological importance and the second in what regards biomass (Table 7). Like the previous station, $2 / 3$ of the individuals are $2.5 \mathrm{~cm}$ in diameter and less than $8 \mathrm{~m}$ in height (Figures $17 \quad \& \quad 18$ ). With only fourteen individuals Swieteniaaubrevilleanahas the greatest distribution of age classes (diameters ranging from 15 to 70 $\mathrm{cm}$ and heights from 8 to $45 \mathrm{~m}$; Figures 17 and 18). This damaged station essentially consists of regenerations at different development stages $(2.5-5 \mathrm{~cm}, 1-8 \mathrm{~m}$; Figures 17 and 18) and some mature specimens of Swieteniaaubrevilleana and Swieteniamacrophyllabelonging to a previous plant formation. 


\section{International Journal of Science and Research (IJSR) \\ ISSN (Online): 2319-7064}

Index Copernicus Value (2015): 78.96 | Impact Factor (2015): 6.391

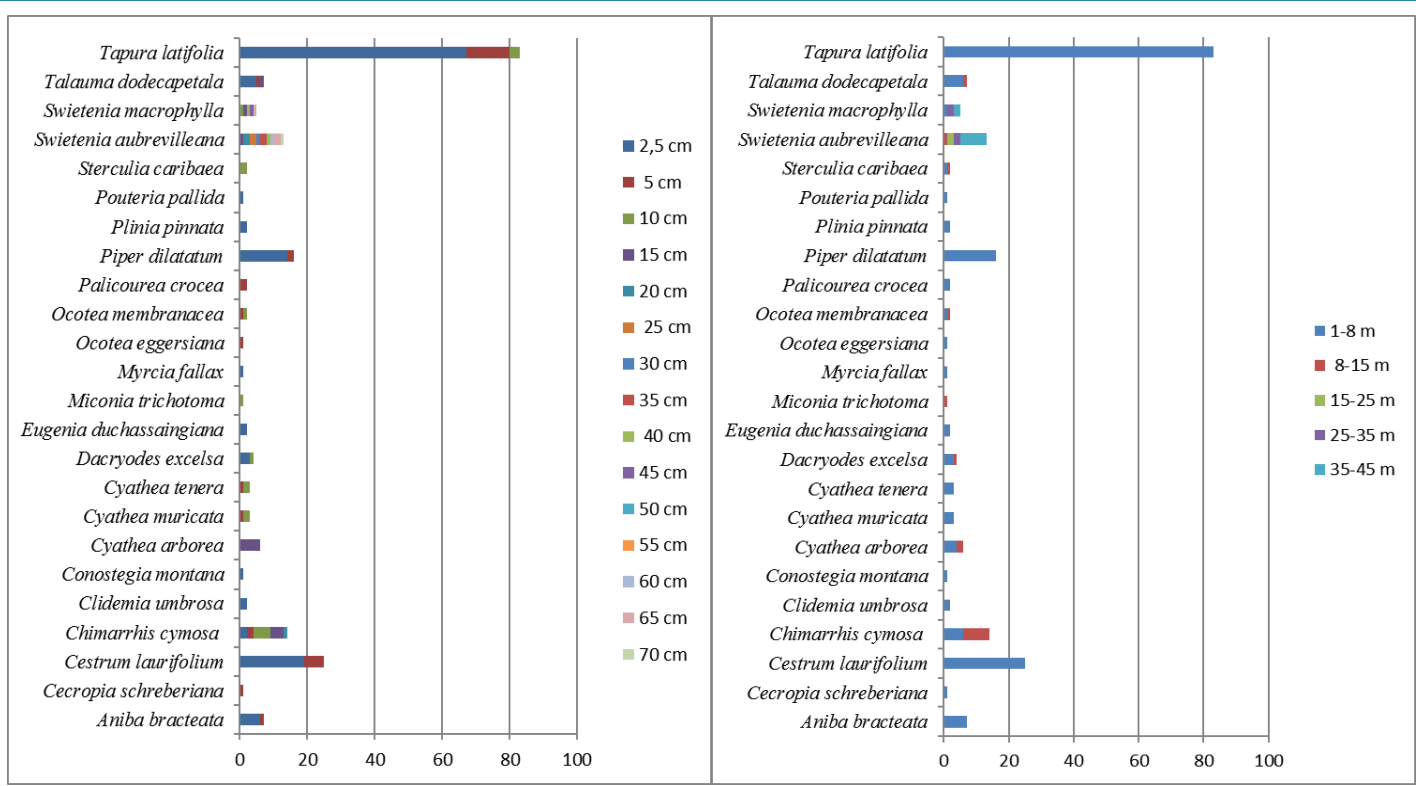

Figure 17: Diametric distribution of trees Figure 18: Distribution of tree heights

Station $4\left(960 \mathrm{~m}^{2}\right.$, Table 8$)$

Table 8: The main descriptors of station 4

\begin{tabular}{|c|c|c|c|c|c|c|c|c|}
\hline Species & Family & $\begin{array}{c}\text { Absolute } \\
\text { Frequency }\end{array}$ & $\begin{array}{c}\text { Relative } \\
\text { Frequency }\end{array}$ & $\begin{array}{c}\text { Number of } \\
\text { individuals by } \\
\text { species excluding } \\
\text { regeneration }\end{array}$ & Density & $\begin{array}{c}\text { Distribution } \\
\text { Index }\end{array}$ & $\begin{array}{c}\text { Total basal } \\
\text { area by species }\end{array}$ & $\begin{array}{c}\text { Index of } \\
\text { dominance }\end{array}$ \\
\hline Myrciafallax & Myrtaceae & 10 & $83 \%$ & 53 & 0.05520833 & 0.046006944 & 0.648115625 & 0.02981782 \\
\hline Pisoniafragrans & Nyctaginaceae & 9 & $75 \%$ & 22 & 0.02291667 & 0.0171875 & 0.918940625 & 0.015794292 \\
\hline Eugenia confused & Myrtaceae & 12 & $100 \%$ & 38 & 0.03958333 & 0.039583333 & 0.315471875 & 0.012487428 \\
\hline Croton corylifolius & Euphorbiaceae & 10 & $83 \%$ & 93 & 0.096875 & 0.080729167 & 0.152584375 & 0.012318009 \\
\hline
\end{tabular}

Pre-forest to young evergreen seasonal tropical forest formation in the secondary stage. The anthropogenic and/or natural degradation resulted in the installation of lower stage plant species and the great species diversity recorded in this station. The floristic population includes several species which are indicators of degraded areas such as Eugenia confusa and Pisoniafragrans.

Myrciafallax, Pisoniafragransand Eugenia confusaseem to be the predominant species in order of ecological importance. However, their population is young because half of the individuals have a $2.5 \mathrm{~cm}$ distribution diameter and a height between 1 and $8 \mathrm{~m}$ (Figures 19 and 20). Eugenia confusa has good station distribution (Table 8). Pisoniafragrans and Croton corylifolius have the highest basal area and the largest population (Table 8). In this plant unit, $75 \%$ of individuals are $2.5 \mathrm{~cm}$ in diameter and $91 \%$ peak between 1 and $8 \mathrm{~m}$ (Figures 19 and 20). Only one Pimentaracemosa individual has a $100 \mathrm{~cm}$ diameter (Figure 19). The maximal height in this station is $18 \mathrm{~m}$ (class $15-25$ m) (Figure 20). No species population presents a balance of age classes and heights. 


\section{International Journal of Science and Research (IJSR) \\ ISSN (Online): 2319-7064}

Index Copernicus Value (2015): 78.96 | Impact Factor (2015): 6.391

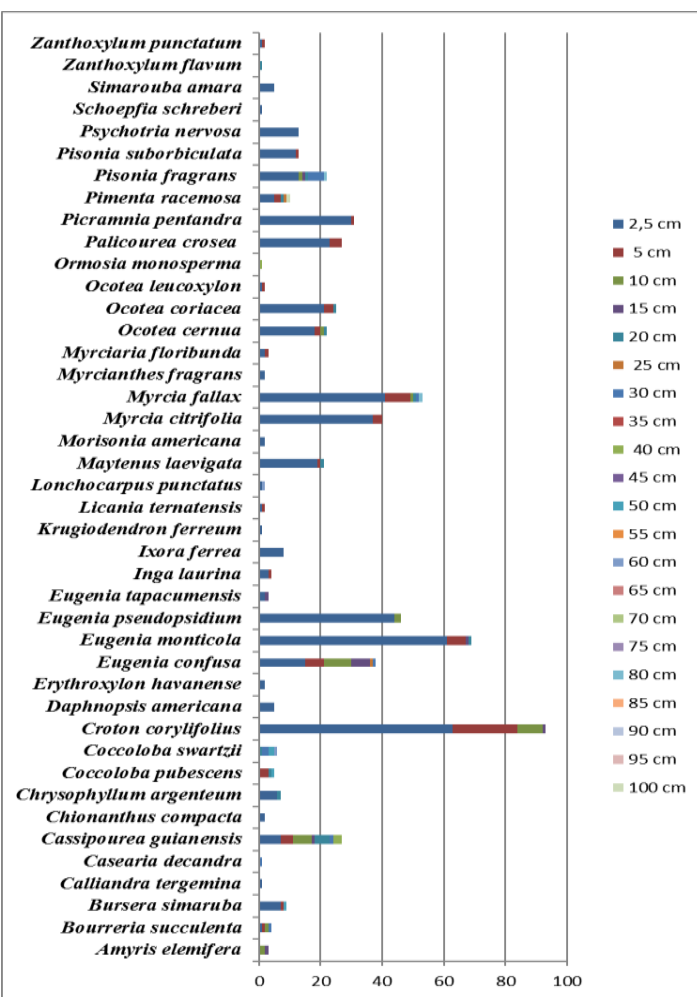

Figure 19: Diametric distribution of trees

Station $5\left(700 \mathrm{~m}^{2}\right.$, Table 9)

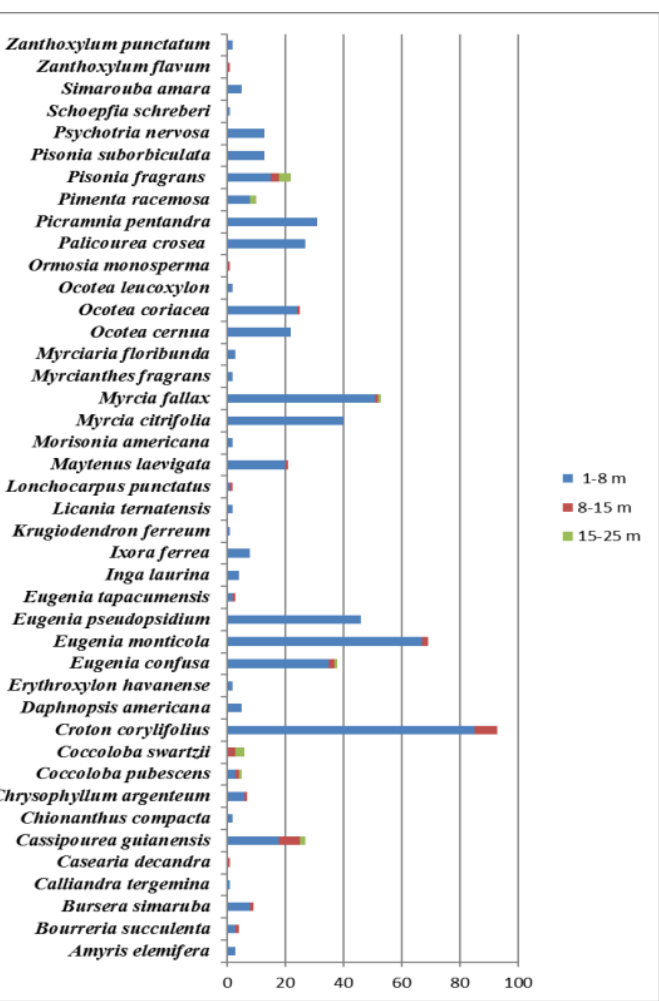

Figure 20: Distribution of tree heights

Table 9: The main descriptors of station 5

\begin{tabular}{|c|c|c|c|c|c|c|c|c|}
\hline Species & Family & $\begin{array}{c}\text { Absolute } \\
\text { Frequency }\end{array}$ & $\begin{array}{c}\text { Relative } \\
\text { Frequency }\end{array}$ & $\begin{array}{c}\text { Number of individuals } \\
\text { by species excluding } \\
\text { regeneration }\end{array}$ & Density & $\begin{array}{c}\text { Distribution } \\
\text { Index }\end{array}$ & $\begin{array}{c}\text { Total basal } \\
\text { area by species }\end{array}$ & $\begin{array}{c}\text { Index of } \\
\text { dominance }\end{array}$ \\
\hline Myrciafallax & Myrtaceae & 10 & $100 \%$ & 78 & 0.111142857 & 0.1111428571 & 0.296828125 & 0.033075134 \\
\hline Cassipoureaguianensis & Rhizophoraceae & 10 & $100 \%$ & 52 & 0.07428571 & 0.074285714 & 0.27965625 & 0.020774464 \\
\hline Pimentaracemosa & Myrtaceae & 6 & $60 \%$ & 14 & 0.02 & 0.012 & 1.09016875 & 0.013082025 \\
\hline
\end{tabular}

Pre-forest to young evergreen seasonal tropical (mesophilic) forest formation in the secondary stage. Myrciafallax and Cassipoureaguianensis predominate in ecological order (Table 9). They have good station distribution (frequencies) and the most important populations (Table 9). Their populations are composed of individuals in morphogenetic development with diameters of $2.5 \mathrm{~cm}$ to $15 \mathrm{~cm}$ for Myrciafallax, from $2.5 \mathrm{~cm}$ to $20 \mathrm{~cm}$ for Cassipoureaguianensis (Figure 21). For individuals of these species the heights range between 1 and $15 \mathrm{~m}$ (Figure 22). Despite a weak population, Pimentaracemosa has the highest basal area (Table 9). The two oldest individuals in the station (class 70 and $80 \mathrm{~cm}$; Figure 21) enable it to occupy the third place in order of ecological importance.
$92 \%$ of the individuals have small diameters $(2.5$ and $5 \mathrm{~cm})$ and peak between 1 and $8 \mathrm{~m}$ (Figures 21 and 22).

This plant unit includes pioneer species, while others like Pimentaracemosa settle very early in the plant succession and participate in all phases of forest evolution up to the climax with population variations. It has the same characteristics as the previous one (station 4). However, station 5 is more advanced because the number of species and the level of degradation are lower. Among the pioneer species some have not been surveyed and those that have been exhibit weak demography. This station is also characterised by an important grassy carpet, mainly consisting of Odontonemanitidum (approximately 646 individuals 1 to $2.5 \mathrm{~m}$ in height and seedlings). 


\section{International Journal of Science and Research (IJSR) \\ ISSN (Online): 2319-7064}

Index Copernicus Value (2015): 78.96 | Impact Factor (2015): 6.391

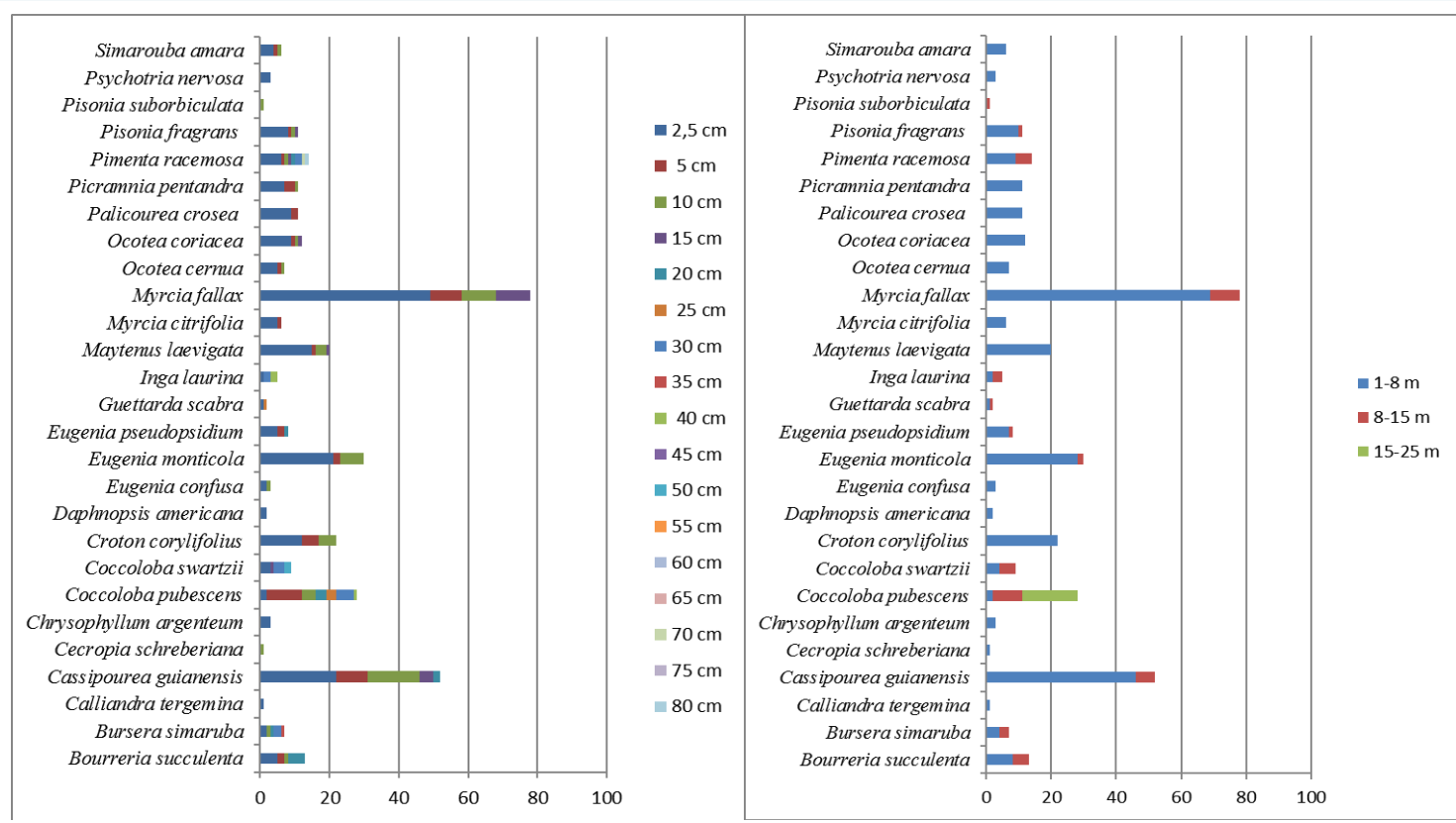

Figure 21: Diametric distribution of trees

Station $6\left(500 \mathrm{~m}^{2}\right.$, Table 10)

Table 10: The main descriptors of station 6

\begin{tabular}{|c|c|c|c|c|c|c|c|c|}
\hline Species & Family & $\begin{array}{c}\text { Absolute } \\
\text { Frequency }\end{array}$ & $\begin{array}{c}\text { Relative } \\
\text { Frequency }\end{array}$ & $\begin{array}{c}\text { Number of individuals } \\
\text { by species excluding } \\
\text { regeneration }\end{array}$ & Density & $\begin{array}{c}\text { Distribution } \\
\text { Index }\end{array}$ & $\begin{array}{c}\text { Total basal } \\
\text { area by species }\end{array}$ & $\begin{array}{c}\text { Index of } \\
\text { dominance }\end{array}$ \\
\hline Myrciafallax & Myrtaceae & 10 & $100 \%$ & 49 & 0.098 & 0.098 & 0.1471875 & 0.014424375 \\
\hline Cassipoureaguianensis & $\begin{array}{c}\text { Rhizophor } \\
\text { aceae }\end{array}$ & 8 & $80 \%$ & 37 & 0.074 & 0.0592 & 0.2099875 & 0.01243126 \\
\hline Ocoteaeggersiana & Lauraceae & 5 & $50 \%$ & 14 & 0.028 & 0.014 & 0.53281875 & 0.007459463 \\
\hline
\end{tabular}

Pre-forest to young evergreen seasonal tropical (mesophilic) forest formation, degraded and damaged by cyclones. The predominant floristic population is the same as that of the previous station (station 5; Table 9). In order of ecological importance Myrciafallax and Cassipoureaguianensis dominate. Myrciafallaxis present in all quadrats and has the largest population (Table 10). Cassipoureaguianensis is second in order of demographic importance and biomass (basal area). With its numbers and average station distribution, Ocoteaeggersiana has the most important basal area (Table 10). $80 \%$ of individuals have a diameter ranging between $2.5-5 \mathrm{~cm}$ and $93.7 \%$ have a height between 1 and 8 m (Figures 23 and 24). Myrciafallax and Cassipoureaguianensis have a diametric and architectural distribution between $2.5 \mathrm{~cm}$ and $20 \mathrm{~cm}$ and 1 and $15 \mathrm{~m}$
(Figures 23 \& 24). Only eight individuals range between 30 and $70 \mathrm{~cm}$ in diameter (Figure 23). This station is in a regression configuration caused by recent anthropogenic and/or natural damage. The mortality rate is $24.4 \%$. The dead cyclone-damaged trees standing or lying on the ground are of varying size (from 10 to $40 \mathrm{~cm}, 2 / 3$ of which are 40 $\mathrm{cm}$ in diameter). The wind created gaps that allowed the installation of pioneer species. However, the floristic population, mainly consisting of Ocoteaeggersiana, Eugenia pseudopsidium and Pimentaracemosa (seedlings and trees in morphogenetic development; some individuals are 40, 50 or $60 \mathrm{~cm}$ in diameter; Figure 23) indicates that in the past it was an advanced and structured vegetation formation. Compared to the other two mesophilic stations in the same area (stations 4 and 5), it is in a more advanced stage. 


\section{International Journal of Science and Research (IJSR) \\ ISSN (Online): 2319-7064}

Index Copernicus Value (2015): 78.96 | Impact Factor (2015): 6.391

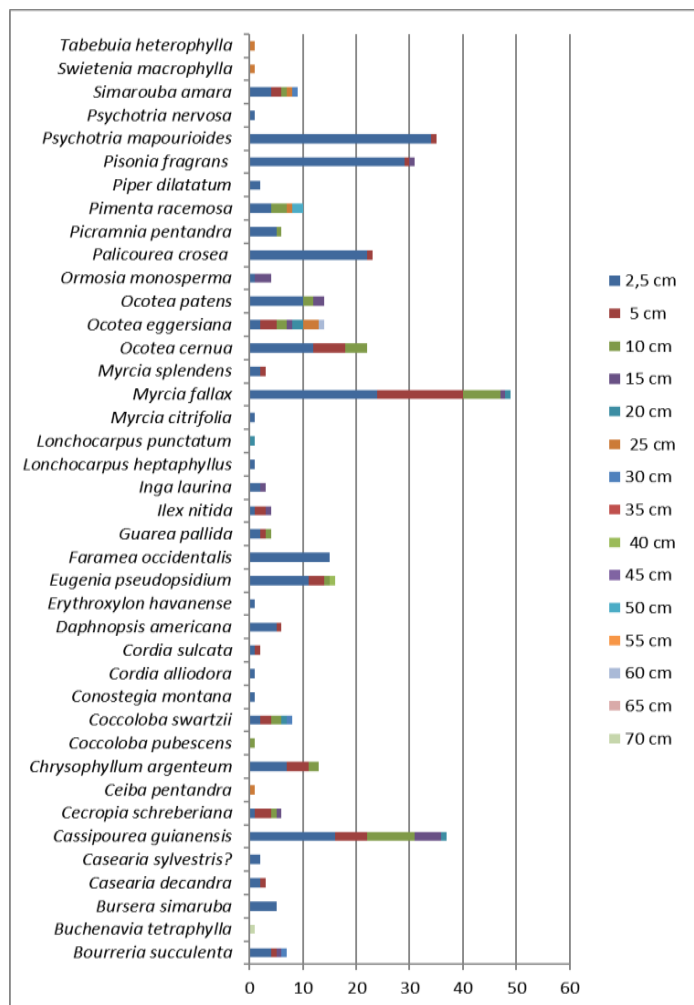

Figure 23: Diametric distribution of trees

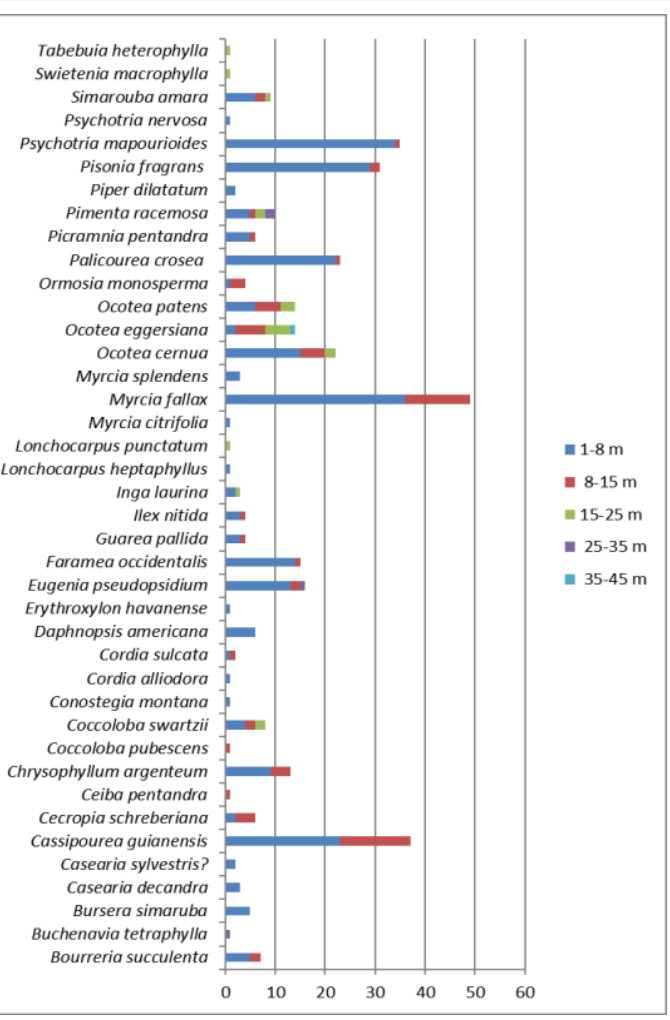

Figure 24: Distribution of tree heights

Station 7 (800 $\mathrm{m}^{2}$, Table 11)

Table 11: The main descriptors of Station 7

\begin{tabular}{|c|c|c|c|c|c|c|c|c|}
\hline Species & Family & $\begin{array}{c}\text { Absolute } \\
\text { Frequency }\end{array}$ & $\begin{array}{c}\text { Relative } \\
\text { Frequency }\end{array}$ & $\begin{array}{l}\text { Number of } \\
\text { individuals by } \\
\text { species } \\
\text { excluding } \\
\text { regeneration }\end{array}$ & Density & $\begin{array}{c}\text { Distribution } \\
\text { Index }\end{array}$ & $\begin{array}{c}\text { Total basal } \\
\text { area by species }\end{array}$ & $\begin{array}{c}\text { Index of } \\
\text { dominance }\end{array}$ \\
\hline Inga laurina & Mimosaceae & 8 & $100 \%$ & 82 & 0.1025 & 0.1025 & 0.56618125 & 0.058033578 \\
\hline Cordiasulcata & Boraginaceae & 6 & $75 \%$ & 52 & 0.065 & 0.04875 & 0.947396875 & 0.046185598 \\
\hline Citharexylumspinosum & Verbenaceae & 7 & $88 \%$ & 23 & 0.02875 & 0.02515625 & 0.41605 & 0.010466258 \\
\hline Tabernaemontanacitrifolia & Apocynaceae & 8 & $100 \%$ & 93 & 0.11625 & 0.11625 & 0.075065625 & 0.008726379 \\
\hline Cupaniaamericana & Sapindaceae & 8 & $100 \%$ & 36 & 0.045 & 0.045 & 0.0843875 & 0.003797438 \\
\hline
\end{tabular}

Pre-forest to young evergreen seasonal tropical (mesophilic) forest formation, secondary and (anthropized). Inga laurina, Cordiasulcata and Citharexylumspinosum are the dominant species in order of importance (Table 11). Their diametric distributions and their heights are relatively well balanced within the station (Figures 25 and 26). Inga laurina, Tabernaemontacitrifolia and Cupaniaamericanaare present in all stations (Table 11). Cordiasulcatahas the highest land surface (basal area) in spite of a density almost half as low as Inga laurina(Table 11). Tabernaemontacitrifolia has the largest population. $73.3 \%$ of the surveyed individuals have a $2.5 \mathrm{~cm}$ diameter and $80.3 \%$ of them peak between 1 and $8 \mathrm{~m}$ (Figures 25 and 26). This degraded station is composed of regenerations and trees that are at different stages of their development. This station is undergoing a recolonization phase. The largest diameter is average: $45 \mathrm{~cm}$. 


\section{International Journal of Science and Research (IJSR) \\ ISSN (Online): 2319-7064}

Index Copernicus Value (2015): 78.96 | Impact Factor (2015): 6.391

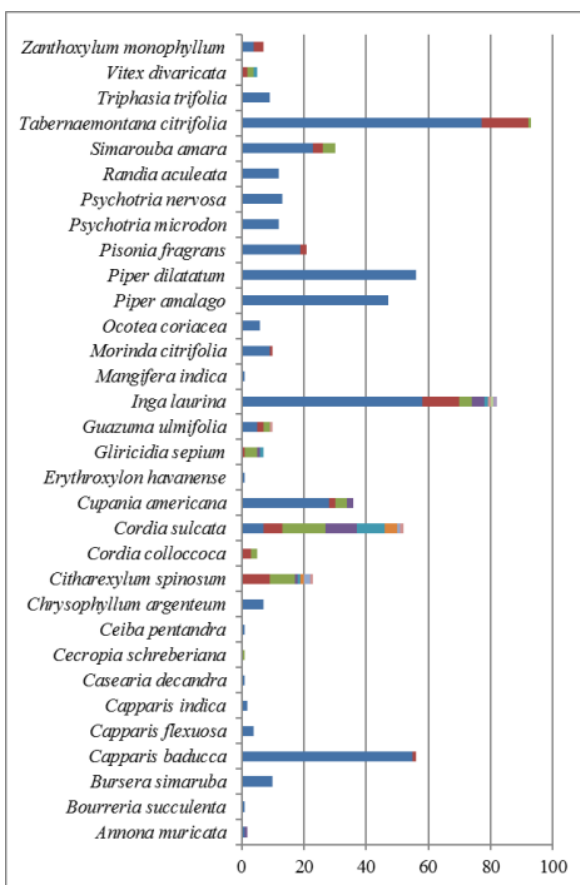

Figure 25: Diametric distribution of trees

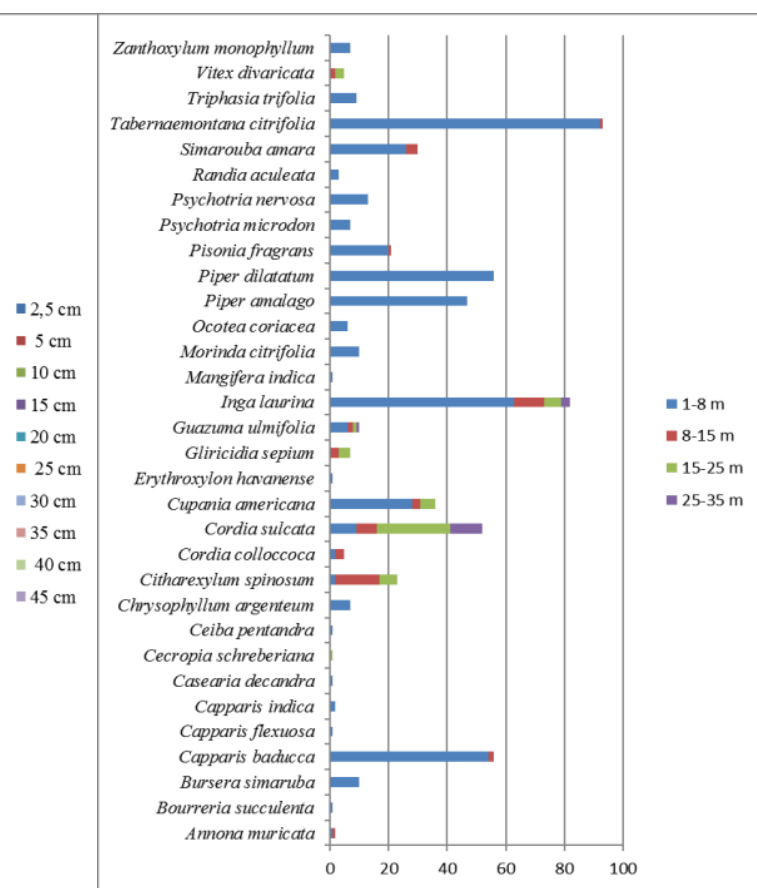

Figure 26: Distribution of tree heights Station $8\left(700 \mathrm{~m}^{2}\right.$, Slope station, Table 12)

Table 12: The main descriptors of station 8

\begin{tabular}{|c|c|c|c|c|c|c|c|c|}
\hline Species & Family & $\begin{array}{c}\text { Absolute } \\
\text { Frequency }\end{array}$ & $\begin{array}{c}\text { Relative } \\
\text { Frequency }\end{array}$ & $\begin{array}{c}\text { Number of } \\
\text { individuals by } \\
\text { species excluding } \\
\text { regeneration }\end{array}$ & Density & $\begin{array}{c}\text { Distribution } \\
\text { Index }\end{array}$ & $\begin{array}{c}\text { Total basal } \\
\text { area by species }\end{array}$ & $\begin{array}{c}\text { Index of } \\
\text { dominance }\end{array}$ \\
\hline Pisoniafragrans & Nyctaginaceae & 7 & $100 \%$ & 214 & 0.30571429 & 0.305714286 & 0.23451875 & 0.071695732 \\
\hline Lonchocarpus punctatus & Fabaceae & 6 & $86 \%$ & 26 & 0.03714286 & 0.031836735 & 1.012159375 & 0.032223849 \\
\hline Burserasimaruba & Burseraceae & 7 & $100 \%$ & 27 & 0.03857143 & 0.038571429 & 0.702575 & 0.027099321 \\
\hline
\end{tabular}

Pre-forest to young evergreen seasonal tropical forest formation of lower horizon and xeric facies in the secondary and degraded stage dominated by a population of Pisoniafragrans regenerations (diameters between $2.5 \mathrm{~cm}$ and $10 \mathrm{~cm}$ and heights between 1 and $15 \mathrm{~m}$; Figures 27 and 28). Pisoniafragans, Lonchocarpus punctatus and Burserasimarubaare the dominant species (Table 12). Despite a weak population, Lonchocarpus punctatus has the highest land surface (basal area) (Table 12) and is the only species with an almost balanced distribution of age classes (Figure 27). Burserasimarubais also a regenerating species, however, three mature specimens (diameters $40 \mathrm{~cm}$ and 60 $\mathrm{cm}$ ) allow it to have a large basal area (second after Lonchocarpus punctatus).

$77.2 \%$ of the individuals have a $2.5 \mathrm{~cm}$ diameter and $77.1 \%$ peak under $8 \mathrm{~m}$ (Figures 27 and 28). This slope station exposed to high insolation is composed of regenerations in different stages of development and a few old Lonchocarpus punctatus and Burserasimarubaindividuals (Figure 27). 


\section{International Journal of Science and Research (IJSR) \\ ISSN (Online): 2319-7064}

Index Copernicus Value (2015): 78.96 | Impact Factor (2015): 6.391

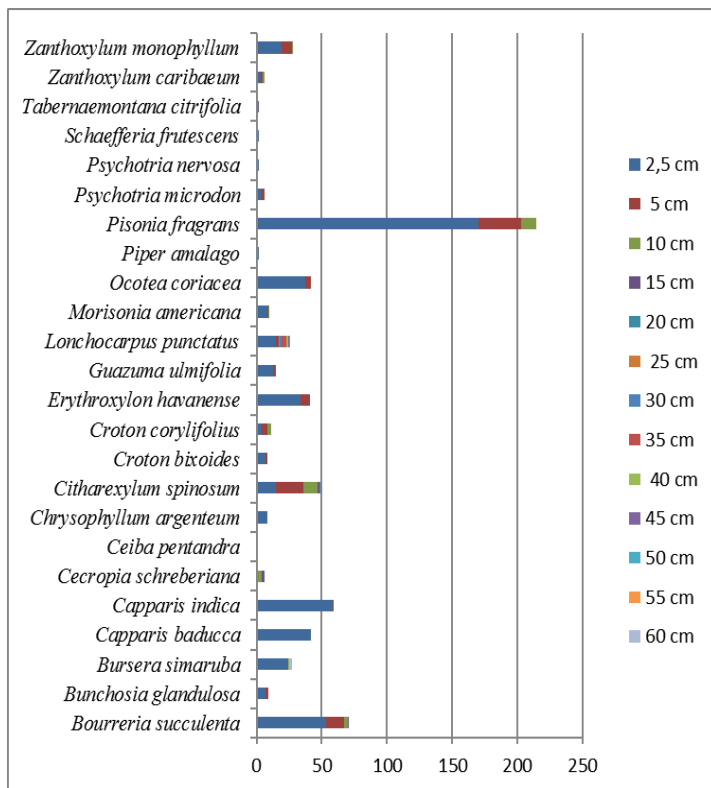

Figure 27: Diametric distribution of trees

Station $9\left(600 \mathrm{~m}^{2}\right.$, Table 13)

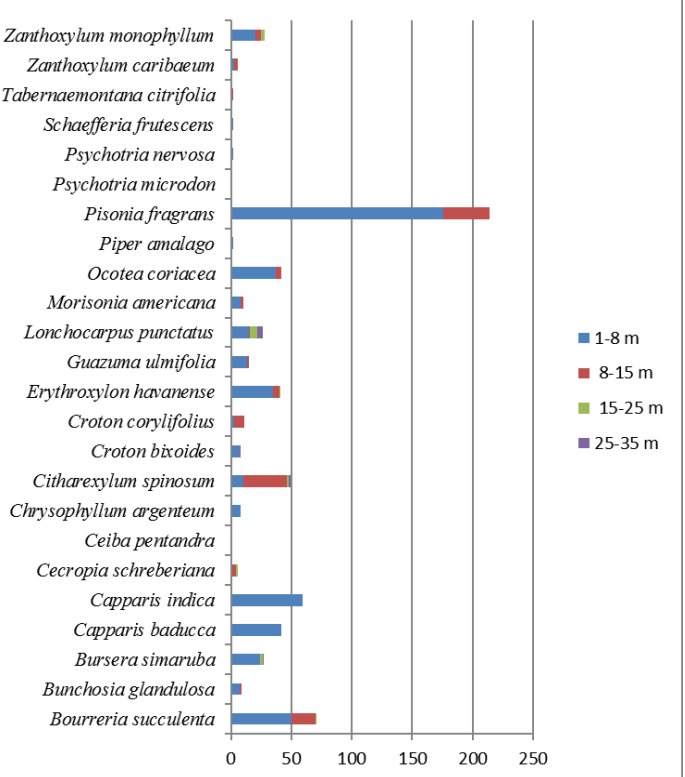

Figure 28: Distribution of tree heights

Table 13: The main descriptors of station 9

\begin{tabular}{|c|c|c|c|c|c|c|c|c|}
\hline Species & Family & $\begin{array}{c}\text { Absolute } \\
\text { Frequency }\end{array}$ & $\begin{array}{c}\text { Relative } \\
\text { Frequency }\end{array}$ & $\begin{array}{c}\text { Number of } \\
\text { individuals by } \\
\text { species excluding } \\
\text { regeneration }\end{array}$ & Density & $\begin{array}{c}\text { Distribution } \\
\text { Index }\end{array}$ & $\begin{array}{c}\text { Total basal } \\
\text { area by } \\
\text { species }\end{array}$ & $\begin{array}{c}\text { Index of } \\
\text { dominance }\end{array}$ \\
\hline Pisoniafragrans & Nyctaginaceae & 6 & $100 \%$ & 154 & 0.25666667 & 0.256666667 & 0.404765625 & 0.103889844 \\
\hline $\begin{array}{c}\text { Lonchocarpus } \\
\text { punctatus }\end{array}$ & Fabaceae & 6 & $100 \%$ & 31 & 0.05166667 & 0.051666667 & 0.49455 & 0.02555175 \\
\hline Capparisindica & Capparaceae & 6 & $100 \%$ & 103 & 0.17166667 & 0.171666667 & 0.079971875 & 0.013728505 \\
\hline
\end{tabular}

Pre-forest to young evergreen seasonal tropical forest formation of lower horizon and xeric facies, secondary and dominated by Pisoniafragrans. The predominant floristic population is the same as that of the previous station (station 8; Table 12) with Pisoniafragransand Lonchocarpus punctatus in order of ecological importance (Table 13). These dominant species are present in all quadrats. Pisoniafragrans has the highest number of individuals, density and indices; but Lonchocarpus punctatus has the most important land surface (basal area) (Table 13). After Pisoniafragans, Capparisindica has the highest density, however its population is characterised by small sections $(2.5 \mathrm{~cm}$ and $5 \mathrm{~cm}$ diameters; Figure 29). This degraded and recolonized plant unit is composed of regenerations: $91 \%$ of the individuals have a diameter ranging between $2.5-5 \mathrm{~cm}$ and a height between 1 and $15 \mathrm{~m}$ (Figures 29 and 30). Only five individuals range between 30 and $60 \mathrm{~cm}$ in diameter (Figure 29).

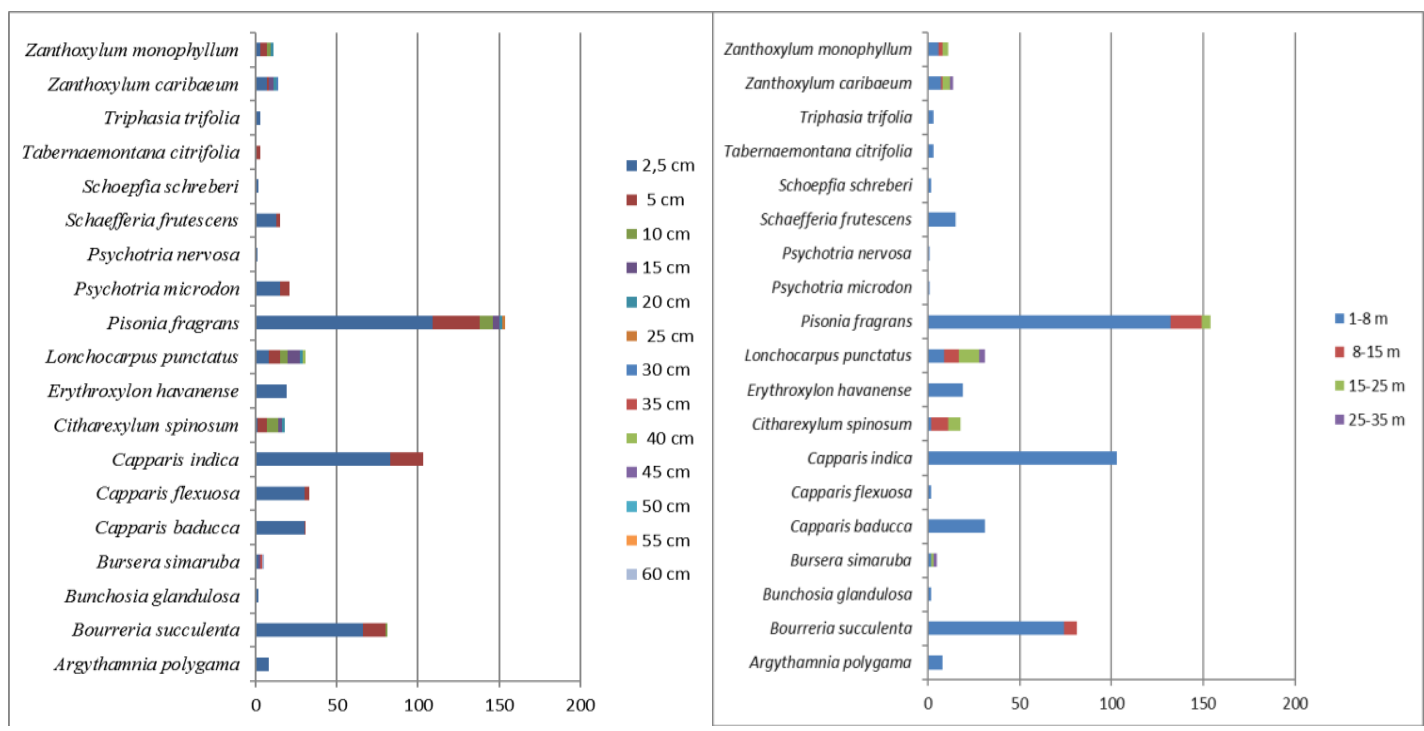

Figure 29: Diametric distribution of treesFigure 30: Distribution of tree heights

\section{Volume 6 Issue 1, January 2017 www.ijsr.net}




\section{International Journal of Science and Research (IJSR) \\ ISSN (Online): 2319-7064}

Index Copernicus Value (2015): 78.96 | Impact Factor (2015): 6.391

4.4 The species dominance ratios between stations of the same bioclimate

Stations 1, 2, $3\left(2370 \mathrm{~m}^{2}\right.$, Table 14)

Table 14: The main descriptors of the wet bioclimate stations

\begin{tabular}{|c|c|c|c|c|c|c|c|c|}
\hline Species & Family & $\begin{array}{c}\text { Absolute } \\
\text { Frequency }\end{array}$ & $\begin{array}{c}\text { Relative } \\
\text { Frequency }\end{array}$ & $\begin{array}{c}\text { Number of individuals } \\
\text { by species excluding } \\
\text { regeneration }\end{array}$ & Density & $\begin{array}{c}\text { Distribution } \\
\text { Index }\end{array}$ & $\begin{array}{c}\text { Total basal } \\
\text { area by } \\
\text { species }\end{array}$ & $\begin{array}{c}\text { Index of } \\
\text { dominance }\end{array}$ \\
\hline Chimarrhiscymosa & Rubiaceae & 3 & $100 \%$ & 41 & 0.01729958 & 0.017299578 & 2.45018125 & 0.042387102 \\
\hline $\begin{array}{c}\text { Swieteniaaubreville } \\
\text { ana }\end{array}$ & Meliaceae & 2 & $67 \%$ & 29 & 0.01223629 & 0.008157525 & 3.285225 & 0.026799304 \\
\hline Tapuralatifolia & Dichapetalaceae & 3 & $100 \%$ & 110 & 0.0464135 & 0.046413502 & 0.53085625 & 0.024638898 \\
\hline
\end{tabular}

Chimarrhiscymosa,

Swieteniaaubrevilleanaand

Tapuralatifolia are the most competing species in terms of environmental factors. Chimarrhiscymosaand Tapuralatifolia are present in the three hygrophilous formations with population variations (Table 14). Swieteniaaubrevilleana has the highest basal area (Table 14). The Chimarrhiscymosa and Swieteniaaubrevilleana populations have a fairly balanced age-class structure (Figures 13, 15 and 17). They consist of seedlings, regenerations and individuals of varying diameters (from $2.5 \mathrm{~cm}$ to $95 \mathrm{~cm}$ ) which peak between 1 and $35 \mathrm{~m}$. Their large basal area is explained by a majority of individuals with important biovolumes. Tapuralatifolia has the highest density but a much smaller basal area than the two other species (Table 14). Its population consists mainly of seedlings, regenerations and individuals in morphogenetic development ( 2.5 to $40 \mathrm{~cm}$ in diameter) which peak between 1 and $25 \mathrm{~m}$ (five individuals range between 20 and $40 \mathrm{~cm}$ in diameter and 15 to $25 \mathrm{~m}$ in height) (Figures 13 to 18). The tree volume and the floristic matrix composed of species like Tapuralatifolia (climax species of the middle horizon of the hygrophilous forest) $[7,20,24]$ indicate a degradation and a regression of these plant formations.

The latter consist of discontinuous strata composed of herbaceous plants, shrubs, developing trees and some mature individuals belonging to previous dynamic stages. The existing forests consist of phytocenoses originating from the successive dynamic stages under anthropic and/or natural constraints. Several dynamic stages mingle and turn these forests into multiple eco-units.

Stations 4, 5, $6\left(2160 \mathrm{~m}^{2}\right.$, Table 15)

Table 15: The main descriptors for the wet sub-humid bioclimate stations

\begin{tabular}{|c|c|c|c|c|c|c|c|c|}
\hline Species & Family & $\begin{array}{c}\text { Absolute } \\
\text { Frequency }\end{array}$ & $\begin{array}{c}\text { Relative } \\
\text { Frequency }\end{array}$ & $\begin{array}{c}\text { Number of } \\
\text { indiduals by } \\
\text { species } \\
\text { excluding } \\
\text { regeneration }\end{array}$ & Density & $\begin{array}{c}\text { Distribution } \\
\text { Index }\end{array}$ & $\begin{array}{c}\text { Total basal } \\
\text { area by } \\
\text { species }\end{array}$ & $\begin{array}{c}\text { Index of } \\
\text { dominance }\end{array}$ \\
\hline Myrciafallax & Myrtaceae & 3 & $100 \%$ & 180 & 0.08333333 & 0.083333333 & 1.09213125 & 0.091010937 \\
\hline Cassipoureaguianensis & Rhizophoraceae & 3 & $100 \%$ & 116 & 0.0537037 & 0.053703704 & 1.170140625 & 0.062840885 \\
\hline Pimentaracemosa & Myrtaceae & 3 & $100 \%$ & 34 & 0.01574074 & 0.015740741 & 2.429084375 & 0.038235587 \\
\hline
\end{tabular}

Myrciafallax,

Cassipoureaguianensis and Pimentaracemosaare the three dominant species. They are present in the three mesophilic stations (Table 15). They seem to be the most apt to develop under the environmental conditions. This dominant floristic population is the same as in Station 5 (Table 9). Similarly, the first two species are also dominant in stations 5 and 6 (Tables 9 and 10). Myrciafallaxis predominant in all mesophilic stations (Tables 8, 9, 10). It has one of the highest number of individuals, density and distribution indices (Table 15). It seems to be the most competing. Despite low total demographics, Pimentaracemosa has the largest total basal area (Table 15). This species settles very early in the plant succession and participates in all phases of forest evolution (from the pioneer stage to the climax) with demographic variations.
Compared to the other two station groups, these stations have the greatest species diversity (Tables 2 and 4). They are also characterised by an important Odontonemanitidum grass carpet, a species of the mesophilic forest undergrowth (seedlings and regenerations: approximately 1196 individuals recorded between 1 and 2.5 in height).

$80.1 \%$ of the individuals have a diameter of 2.5 to $5 \mathrm{~cm}$. None of the three species exhibits an age-class balance. These degraded secondary plant units consist of pioneer species, individuals with small sections and a few large diameter specimens, in principal Myrciafallax $(80 \mathrm{~cm}$, station 4; Figure 19) Pimentaracemosa(70, 80, $100 \mathrm{~cm}$; stations 4 and 5; Figures 19 and 21) and Pisoniafragrans $(80 \mathrm{~cm}$, station 4; Figure 19) belonging to past dynamic stages. The anthropic and/or natural parameters caused the regression of these formations. The current floristic matrix is composed of individuals in different dynamic stages.

Stations 7, 8, $9\left(2100 \mathrm{~m}^{2}\right.$, Table 16)

Volume 6 Issue 1, January 2017 www.ijsr.net 


\section{International Journal of Science and Research (IJSR) \\ ISSN (Online): 2319-7064}

Index Copernicus Value (2015): 78.96 | Impact Factor (2015): 6.391

Table 16: The main descriptors of the dry sub-humid bioclimate stations

\begin{tabular}{|c|c|c|c|c|c|c|c|c|}
\hline Species & Family & $\begin{array}{l}\text { Absolute } \\
\text { Frequency }\end{array}$ & $\begin{array}{l}\text { Relative } \\
\text { Frequency }\end{array}$ & \begin{tabular}{|} 
Number of \\
individuals by \\
species \\
excluding \\
regeneration
\end{tabular} & Density & $\begin{array}{l}\text { Distribution } \\
\text { Index }\end{array}$ & $\begin{array}{c}\text { Total basal } \\
\text { area by } \\
\text { species }\end{array}$ & $\begin{array}{c}\text { Index of } \\
\text { dominance }\end{array}$ \\
\hline Pisoniafragrans & Nyctaginaceae & 3 & $100 \%$ & 389 & 0.1852381 & 0.185238095 & 0.65253125 & 0.120873646 \\
\hline Lonchocarpus punctatus & Fabaceae & 3 & $100 \%$ & 57 & 0.02714286 & 0.027142857 & 1.506709375 & 0.040896397 \\
\hline Citharexylumspinosum & Verbenaceae & 3 & $100 \%$ & 90 & 0.04285714 & 0.042857143 & 0.765375 & 0.032801786 \\
\hline
\end{tabular}

Station 7 (Table 11) is a mesophilic formation while the other two (8 and 9; Tables 12 and 13) are xerophytic. This floristic population is influenced by the mesological factors and mainly by the wet bioclimate which allowed the installation of certain species of the mesophilic environment such as Cupaniaamericana, Odontonemanitidum or Piper amalago. Certain topographical and ecosystem characteristics are responsible for the spatial extension of the plant species outside their main distribution area [24]. Pisoniafragrans, Lonchocarpus punctatus and Citharexylumspinosum are the dominant species for these three stations (Table 16). They have good intra-stationary distribution with demographic variations (Figures 25, 27, 29). Pisoniafragrans and Lonchocarpus punctatus are also preponderant in stations 8 and 9. Pisoniafragrans is the most competing species with the largest population and the highest density and distribution and dominance indices
(Table 16). Its population is composed of regenerations of various sizes and trees in morphogenetic development with diameters between $2.5 \mathrm{~cm}$ and $25 \mathrm{~cm}$ and heights between 1 and $25 \mathrm{~m}$. Lonchocarpus punctatus has the highest basal area (Table 16). Its population as well as that of Citharexylumspinosum has a balanced diametric structure ranging between $2.5 \mathrm{~cm}$ and $50 \mathrm{~m}$ for Lonchocarpus punctatus and between $2.5 \mathrm{~cm}$ and $35 \mathrm{~cm}$ for Citharexylumspinosum. The floristic population of this area is made up of small diameter individuals and of some volume trees such as Burserasimaruba and Ceibapentendra (Figures 26, 28, 30). This configuration is due to a high rate of anthropogenic degradation. These plant formations are relatively young, dominated by pioneer species and colonize an anthropized site. They are characteristic of a degraded, secondary or recolonized lower floor [7, 20,24].

\subsection{The species dominance ratios for all stations}

Table 17: The main descriptors for all stations

\begin{tabular}{|c|c|c|c|c|c|c|c|c|}
\hline Species & Family & $\begin{array}{c}\text { Absolute } \\
\text { Frequency }\end{array}$ & $\begin{array}{c}\text { Relative } \\
\text { Frequency }\end{array}$ & $\begin{array}{c}\text { Number of } \\
\text { individuals by } \\
\text { species excluding } \\
\text { regeneration }\end{array}$ & Density & $\begin{array}{c}\text { Distribution } \\
\text { Index }\end{array}$ & $\begin{array}{c}\text { Total basal } \\
\text { area by } \\
\text { species }\end{array}$ & $\begin{array}{c}\text { Index of } \\
\text { dominance }\end{array}$ \\
\hline Pisoniafragrans & Nyctaginacea & 6 & $67 \%$ & 453 & 0.06832579 & 0.045550528 & 1.636725 & 0.074553688 \\
\hline Myrciafallax & Myrtaceae & 6 & $67 \%$ & 183 & 0.02760181 & 0.018401207 & 1.1245125 & 0.020692387 \\
\hline Burserasimaruba & Burseraceae & 6 & $67 \%$ & 63 & 0.00950226 & 0.006334842 & 1.58668125 & 0.010051374 \\
\hline
\end{tabular}

Pisoniafragrans, Myrciafallax and Burserasimaruba are the dominant species for all nine studied stations. They are each present in six stations out of nine. Pisoniafragrans is the dominant species with the highest population, density and distribution and dominance indices (Table 17). It is present in xerophytic and mesophilic stations: stations 4 to 9 (Tables 8 to 13). Its biodemography is more important in the xerophytic stations (stations 8 and 9:368) than in the mesophilic stations (stations 4, 5, 6 and 7:85 individuals). This species is ubiquitous since it may be present from the lower to the upper floor (from dry to wet) with population variations [7, 20, 24]. Its main distribution area is the lower degraded or secondary floor and the lower horizon of the middle floor. It may be present in tropical seasonal ombrophilous evergreen (meso-hygrophilous) forests but erratically or with low demography because it is not competitive due to the environmental conditions. Myrciafallax is second in terms of demographics, density and indices (Table 17). This species is present in young mesophilic and hygrophilous formations, particularly in stations 1 to 6 . Nevertheless, it appears to be more competing in mesophilic stations with 180 individuals than in hygrophilous stations with 3 individuals: 1 individual per station (Table 15). Burserasimarubais recorded in the same stations as Pisoniafragrans(Stations 4 to 9) with 32 individuals in the xerophytic stations (stations 8 and 9) and 31 individuals in the mesophilic stations (4, 5, 6 and 7). From an ecological point of view, it is a species of the degraded or secondary tropical seasonal evergreen forest of lower horizon (xeric). Nevertheless, it can sometimes be present in young and disturbed mesophilic forests as shown in surveys 4, 5, 6 and 7. The presence of this post-pioneer species is due to the degradation of the original evergreen seasonal tropical forest vegetation of the lower horizon.

In general, the studied biocenoses are made up of small diameter individuals associated with species and individuals of medium and large volumes originating from a previous dynamic stage. $83 \%$ of the individuals have a diameter between 2.5 and $5 \mathrm{~cm}$ (Figure 31). Only 29 individuals have diameters between 55 and $100 \mathrm{~cm}$ : two of them have a 100 $\mathrm{cm}$ diameter (stations 2 and 4; Figure 31). In all stations, the 1-8 m height class is largely dominant (Figure 32 ). $92.4 \%$ of individuals peak between 1 and 15 meters (Figure 32). Only 17 individuals are $40 \mathrm{~m}$ high (maximal height, stations 2, 3 and 6; Figure 32).

\section{Volume 6 Issue 1, January 2017 www.ijsr.net}




\section{International Journal of Science and Research (IJSR) \\ ISSN (Online): 2319-7064}

Index Copernicus Value (2015): 78.96 | Impact Factor (2015): 6.391

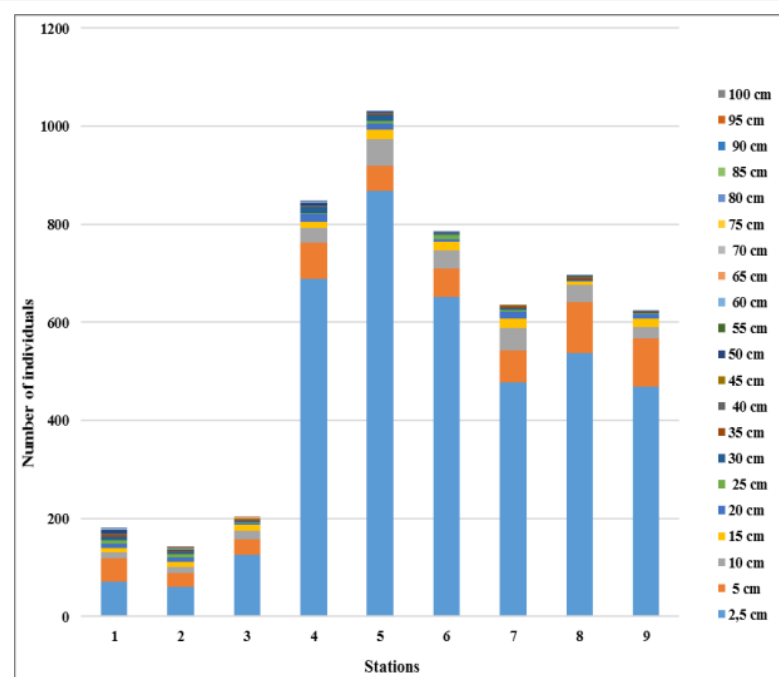

Figure 31: Diameter distribution in the stations

\section{Conclusion}

The various bioclimates and their topographical subdivisions result in specific floristic units, characterised by preponderant species populations [24, 18]. In parallel, a predominant floristic population composed of so-called "indicator" species allows us to determine the bioclimate of an area. The phytocenoses observable today within the various bioclimates are for the most part regression forms of the original forests which are in various dynamic stages depending on the anthropic disturbances [24, 18]. The analysis of the structural and functional processes of Martinique's current phytocenoses require in-depth quantitative floristic surveys and a knowledge of the original plant formations and their evolutions. These types of studies should contribute to a better knowledge of Martinique's flora (structure, function and evolution), supply tools for decisionmaking and should be taken into account in the management policies for the conservation of the floristic heritage resources: with the aim of a balanced and adapted sustainable management of the biotopes and therefore of the biocenoses. In Martinique, as in the other islands of the Lesser Antilles, the plant communities are little redundant; some are even unique, such as the Pterocarpusoffinalis swamp forests of Trinité[7, 24, 6]. In addition, Martinique's biodiversity is subjected to numerous pressures and is currently very vulnerable. The human influence (strong demography and anthropization) sometimes has irreversible consequences on the terrestrial, river and aquatic ecosystems of the island [42]. In addition to the deterioration caused in colonial times, Martinique is also affected by the current global environmental problems (habitat loss, habitat fragmentation, overexploitation of natural resources, the spread of exotic species and diseases, pollution of environmental elements (air, water, soil) and climate changes [43, 44, 19]. Moreover, the habitat loss and habitat fragmentation are undoubtedly the main causes of the erosion of tropical biodiversity [45].

\section{Acknowledgements}

All my gratitude to my thesis supervisor Professor P. JOSEPH for the supervision, the training and the knowledge I received. All my sympathy to my doctoral colleagues and

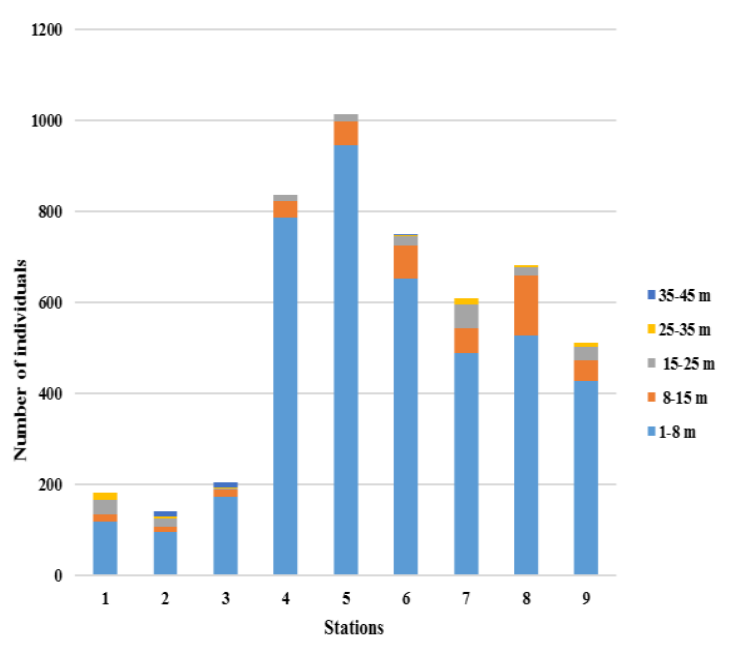

Figure 32: Height distribution in the stations

the other students for their field work. I am also grateful to the former Regional Council of Martinique (the current Territorial Collectivity of Martinique) for their financial aid and to the University of the West Indies (UA).

\section{References}

[1] Singh, J. S.; Bourgeron, P. and Lauenroth, W. K. (1996). «Plant Species Richness and Species-Area Relations in a Shortgrass Steppe in Colorado ». Journal of Vegetation Science, Vol. 7, No. 5, p. 645650.

[2] Ji, Y.; Zhou, G.; New, T. (2009). « Abiotic Factors Influencing the Distribution of Vegetation in Coastal Estuary of the Liaohe Delta, Northeast China ». Estuaries and Coasts, Vol. 32, No. 5, p. 937-942.

[3] Woodward, F. I.; Williams, B. G. (1987). «Climate and Plant Distribution at Global and Local Scales ». Vegetatio, Vol. 69, No. 1/3, Theory and Models in Vegetation Science, p. 189-197.

[4] Zhang, J-T.;Ru, W.; Li, B. (2006). «Relationships between vegetation and climate on the Loess Plateau in China ». FoliaGeobotanica, Vol. 41, No 2, p. 151-163.

[5] Joseph, P. (2009a). «Les espèces ligneuses des «phases climaciques » des forêts des Petites Antilles». Écosystèmes forestiers des Carä̈bes. Actes du colloque organisé par le Conseil Général de la Martinique avec la collaboration de l'Université des Antilles et de la Guyane, 5-10 décembre 2005. Paris : Karthala, p. 261-277.

[6] Joseph, P. (2011). «Les Antilles françaises, véritables laboratoires pour l'étude de l'évolution des systèmes forestiers ». Habitation/Plantation Caraïbe-Amérique. Paris : Éditions Karthala, p. 77-106.

[7] Joseph, P. (1997).Dynamique écophysiologie végétales en bioclimat sec à la Martinique (Antilles Françaises). Thèse de Géographie, Université des Antilles et de la Guyane, 941 p. + annexes.

[8] Brown, S., Lugo, A.E. (1990). « Tropical secondary forests ». Journal of Tropical Ecology, Vol. 6, No 1, p. $1-32$.

[9] Doyscher, R. W. Jr. (1979). « The Lesser Antilles: A Lesson in Conserving Natural Resources ». The American Biology Teacher, Vol. 41, No. 2, p. 86-90.

\section{Volume 6 Issue 1, January 2017 www.ijsr.net}




\section{International Journal of Science and Research (IJSR)

[10] Lugo, A. E., Schmidt, R. and Brown, S. (1981). "Tropical Forests in the Caribbean". Ambio, Vol. 10, No. 6, The Caribbean, pp. 318-324.

[11] Acevedo-Rodríguez, P. and Strong M.T. (2008) «Floristic richness and affinities in the West Indies». BotanicalReview, Vol. 74, No. 1, p. 5-36.

[12] Ricklefs, R.; Bermingham, E. (2008). « The West Indies as a laboratory of biogeography and evolution ». PhilosophicalTransactions :Biological Sciences, Vol. 363, No 1502, p. 2393-2413.

[13] Kimber, C.T. (1988). Martinique revisited. The changing plant geographies of a West Indian island. College Station, TX : Texas A\&M University Press, $258 \mathrm{p}$.

[14] Myers, N., Mittermeier, R.A., Mittermeier, C.G. et al.(2000). «Biodiversity hotspots for conservation priorities ». Nature, No 403, p. 853-858.

[15] Pimm, S.T and Jenkins, C. (2005). «Sustaining the variety of life ». Scient. Amer., Vol. 293, No 3, p. 4451.

[16] Ramade, F. (2007). «Les écosystèmes forestiers des Caraïbes ». Compte rendu de colloque (Martinique 510 décembre 2005). Natures Sciences Sociétés, Vol.15, p.319-321.

[17] Howard, R.A. (1970). "The "Alpine" Plants of the Antilles ». Biotropica, Vol. 2, No., pp. 24-28.

[18] Joseph, P.(2012a). «Quelques traits généraux de la diversité sylvatique des Petites Antilles ». VertigO - la revue électronique en sciences de l'environnement, Hors-série 14. URL: http://vertigo.revues.org/12492; DOI: $10.4000 /$ vertigo.12492

[19] Ramade, F. (2009). «Impact de l'homme moderne sur les forêts tropicales: ses conséquences prévisibles sur la biodiversité planétaire et dans la perspective d'un développement durable ». Écosystèmes forestiers des Caraïbes. Paris : Karthala, p.15-32.

[20] Fournet, J. (2002). Flore illustrée des phanérogames de Guadeloupe et de Martinique. Nouvelle édition. Trinité : Gondwana Éditions, 2 vol., 2538 p.

[21] Etifier-Chalono, E., Bernard, J-F., Deknuydt, F. (2006). «Les zones naturelles d'intérêt écologique faunistique et floristique à la Martinique ». La Caraïbe, données environnementales, p. 271-293.

[22] Sastre, C., et Breuil, A. (2007). Plantes, milieux et paysages des Antilles Françaises : Écologie, biologie,

[35] Joseph, P. (2016a). « The Spatio-Temporal Interfaces within the Lesser Antilles Vegetation (The Example of the Island of Martinique) ». Open Access Library Journal, Vol. $\quad 3, \quad$ e2463. http://dx.doi.org/10.4236/oalib.1102463.

[36] Joseph, P. (2016b). " Trial to comprehend the functioning of the vegetation of the lesser Antilles in the light of the general understanding of vegetation dynamics ». International Journal of Advanced Research (IJAR), Vol. 4, Issue 3, p. 1786-1806.

[37] Joseph, P. (2016c). «Contribution to the knowledge of the vegetation dynamics processes in the Lesser Antilles ». International Journal of Science and Research (IJSR), Vol. 5, Issue 6, p. 466-477.

[38] Météo-France Antilles Guyane, D. M. (2012). Projection Climatique régionalisée en Martinique. Rapport disponible à la demande. identification, protection et usages. Mèze : Biotope, Collection Parthénope, 1 vol., 672 p.

[23] Fiard, J-P. (1992). Arbres rares et menacés de la Martinique. Conseil régional de la Martinique, la Société des Galeries de la géologie et de botanique.

[24] Joseph, P. (2009b). La végétation forestière des Petites Antilles, Synthèse biogéographique et écologique, bilan et perspectives. Paris : Karthala, $490 \mathrm{p}$.

[25] Joseph, P. (2012b). «The vegetation of the Lesser Antilles: floristic diversity and ecosystemic dynamics ». International Journal of EnvironmentalStudies, 18 p.

[26] Joseph, P. (2013a). «Mount Pele, an ecoclimatic gradient generator ». Landscape\&Environment 7 (1), p. 27-41.

[27] Joseph, P. (2013b). «How should the forest types of the Lesser Antilles be described in the intertropical area ». EarthResources 1 (3), p. 78-102.

[28] Joseph, P. (2014a). « The Influence of Vegetation on the Main Macro-Climatic Factors: The Example of the Lower Vegetal Floor of Martinique (Lesser Antilles) ». Open Journal of Botany, Vol. 1, p. 5-18.

[29] Joseph, P. (2014b). « Structure of vegetation formations and floral dynamics in the Lesser Antilles: The example of the lower vegetation level of Martinique ». The Journal of ecology. Photon 109, p. 375-400.

[30] Joseph, P. (2014c). «Environmental politics and space management in the French island of America: some general teachings ». Sylwan, 158 (7), p. 429-456.

[31] Joseph, P. (2015a). «Attempt to understand the relationship between the water of the soil system and the vegetation: the case of the Martinique lower vegetation floor ». Journal of Advances in Biology, Vol. 6, No. 3, p. 1161-1188.

[32] Joseph, P. (2015b). «Plausible ecosystem responses to climate change: The case of vegetation in the Lesser Antilles». International Journal of Advanced Research (IJAR), Vol. 3, Issue 6, p. 657-670.

[33] Joseph, P. (2015c) « The Final Stages of Vegetal Dynamics in the Lesser Antilles (A Few Theories) ». International Journal of Science and Research (IJSR), Vol. 4, Issue 11, p. 1151-1164.

[34] Joseph, P. (2015d). « Climax Phase Forest Species of the Lesser Antilles Forests. International Journal of Recent Research and Review (IJRRR), Vol. VIII, Issue 4, p. 51-69.

[39] Venkatapen, C. (2012). Étude des déterminants géographiques et spatialisation des stocks de carbone des sols de la Martinique. Diss. Antilles-Guyane.

[40] Gillet, F. (2000). La phytosociologie synusiale intégrée. Guide méthodologique. Documents du Laboratoire d'Écologie végétale, Institut de Botanique, Université de Neuchâtel, 68 p.

[41] Braun-Blanquet, J. et Pavillard, J. (1928). Vocabulaire de sociologie végétale. Ardres : Reprod. Imp. Lemaire, $23 \mathrm{p}$.

[42] Baillard, K. (2016). « The effects of anthropization on the coastal island vegetation: the example of the Mangrove forest of the Bay of Fort-de-France (Martinique) ». International Journal of Recent Research and Review (IJRRR), Vol. IX, Issue 2, p. 114.

\section{Volume 6 Issue 1, January 2017} www.ijsr.net 


\section{International Journal of Science and Research (IJSR) \\ ISSN (Online): 2319-7064}

Index Copernicus Value (2015): 78.96 | Impact Factor (2015): 6.391

[43] Soulé, M.E. (1991). «Conservation: tactics for a constant crisis ». Science, New series, Vol. 253, No 5021, p. 744-750.

[44] Ramade, F. (2005). Éléments d'écologie, écologie appliquée. $6^{\mathrm{e}}$ éd. Paris :Dunod, $864 \mathrm{p}$.

[45] Laurance, W.F. (2004). «Forest-climate interactions in fragmented tropical landscapes ». Philosophical Transactions: Biological Sciences, Vol. 359, No 1443, Tropical Forests and Global Atmospheric Change, p. 345-352.

Volume 6 Issue 1, January 2017

www.ijsr.net 